\title{
The Heterogeneous Impact of Sectoral Foreign Aid Inflows on Sectoral Growth: SUR Evidence from Selected Sub-Saharan African and MENA Countries
}

\author{
Nadeem Abdulmalik Abdulrahman Aljonaid ${ }^{1, *}$, , Fengming Qin ${ }^{1}$ and Zhaoyong Zhang ${ }^{2}(\mathbb{D}$ \\ 1 School of Economics, Shandong University, Jinan 250100, China; fmqin@sdu.edu.cn \\ 2 School of Business \& Law, Edith Cowan University, Perth 6027, Australia; zhaoyong.zhang@ecu.edu.au \\ * Correspondence: nadeemaljonaidchina@gmail.com or demoo2018@mail.sdu.edu.cn
}

\section{check for}

Citation: Aljonaid, Nadeem

Abdulmalik Abdulrahman,

Fengming Qin, and Zhaoyong Zhang. 2022. The Heterogeneous Impact of Sectoral Foreign Aid Inflows on Sectoral Growth: SUR Evidence from Selected Sub-Saharan African and MENA Countries. Journal of Risk and Financial Management 15: 107 https://doi.org/10.3390/jrfm15030107 Academic Editor: Thanasis Stengos

Received: 18 January 2022

Accepted: 18 February 2022

Published: 25 February 2022

Publisher's Note: MDPI stays neutral with regard to jurisdictional claims in published maps and institutional affiliations.

Copyright: (C) 2022 by the authors. Licensee MDPI, Basel, Switzerland. This article is an open access article distributed under the terms and conditions of the Creative Commons Attribution (CC BY) license (https:// creativecommons.org/licenses/by/ $4.0 /)$.

\begin{abstract}
A great deal of the foreign aid-growth literature finds that the net effect of aggregate aid on total growth appears to be insignificant. This study argues that this aid-growth nexus can be better explained by testing the variation responses for each of growth sectors to their corresponding allocated aid inflows. It aims to investigate the heterogeneous effects of sectorally allocated aid inflows on their corresponding growth sectors (industry, agriculture and services) using data from 37 Sub-Saharan African and MENA-recipient developing nations from 1996 to 2017. We constructed two measures; one is the (SAASG) Sectoral-Allocated-Aid-for Sectoral-Growth, which was used as a major measure in the first two econometric specifications, and another one was the revised Clemens early-impact aid categories measure, which was used as the secondary measure in the third specification. The seemingly unrelated regression framework (SUR) was employed as the basic estimation approach, while the GMM approach was used to check robustness. The empirical findings revealed clear systematic impacts associated with aid distributed to each sector of growth, which may explain why the net effect of overall aid on total growth appears to be insignificant. The findings show that allocated aid inflows have a strong positive impact on agricultural growth, helping boost overall growth, whereas aid allocated to the service and industrial growth sectors tends to minimize the net benefits of total aid on growth due to financial and institutional reasons. The success of the planned scaling-up of aid to recipient countries depends on the financial system, institutional quality policies, and the ability to design a way to maintain incentives in the MENA and SSA regions' selected recipient countries to overcome structural bottlenecks of sectoral growth.
\end{abstract}

Keywords: sectoral aid; sectoral growth; early-impact aid; foreign aid; financial market; institutional quality; tropical areas

\section{Introduction}

In 2019, inflows of official development assistance (ODA) to the world economies increased from US\$4.27 billion to US\$167.8 billion (WDI 2021). Providing emerging countries and regions, such as Sub-Saharan Africa (SSA) ${ }^{1}$ and the Middle East and North Africa (MENA), with foreign aid inflows in a variety of forms and types, ranging from humanitarian emergency assistance to food aid, military, social and economic assistance, etc., has long been an increasing trend to help them rise out of poverty. With such increased aid inflows of various types and forms, SSA represents the greatest beneficiary, receiving $\$ 55.18$ billion in total ODA in 2019, followed by MENA countries, which received \$29.19 billion (WDI 2021). However, the economic impacts and consequences of foreign aid vary substantially among the recipient countries (Nyoni and Bonga 2017; Shahzad and Qin 2019). A variety of studies on aid's efficacy for growth focused on many aspects, both aggregate and disaggregated, have been conducted in search of an interpretation of this phenomena, but foreign aid remains a highly contentious topic. To summarize, past research at the aggregate level has failed to establish strong and compelling evidence of a positive or 
negative relationship between economic growth and foreign Aid (Rajan and Subramanian 2011). Nonetheless, empirical research on aid efficacy suggests that the effects of targeted and allocated aid at the disaggregated level tend to be positive, whereas the impact of foreign Aid at the aggregated level is more difficult to prove (see, for instance: Jones and Tarp 2016; Bourguignon et al. 2012; Clemens et al. 2004, 2012; Ndikumana 2012; Ndikumana and Pickbourn 2017; Pickbourn and Ndikumana 2016).

Although good positive results in terms of aid disaggregation and sectoral level path have been considered in many developmental areas of aid literature ${ }^{2}$, some important research areas in this path remain unexplored. One of these areas relates to the examination of the responses of growth sectors to their corresponding sectorally allocated aid. The previous literature does not provide a comprehensive theoretical or empirical framework for the potential effect mechanism regarding the impact of sectorally allocated aid on corresponding growth sectors. The previous potential effects mechanism of aid-growth literature at the sectoral and disaggregated level, as debated in Section 2, focused on either the heterogamous effects of sectoral aid on total growth, such as (Clemens et al. 2004, 2012) or the homogeneous total assistance effects on sectoral growth competitiveness (see, for instance: Feeny and Ouattara 2009; Selaya and Thiele 2010; Adam and Bevan 2006; Rajan and Subramanian 2008b). Even though many studies have focused on the effects of aid allocated to agricultural growth, there is no comprehensive systematic empirical examination of sectorally allocated aid on each sector of the growth system at the crosscountry level in the existing literature on the foreign aid-growth nexus. McArthur and Sachs (2019) concluded that there is a need for such research as they found that different aid allocation schemes may result in distinct structural dynamics. Therefore, the current article intends to cover this gap and investigate the impact of sectorally allocated aid on the growth of agriculture, services and industry in 37 recipient nations selected from the MENA and SSA regions. It employs an innovative decomposition analysis and the SUR framework to consider the interdependence among different growth sectors. It also takes into account the most apparent theoretical assumptions of the aid-growth literature to build hypotheses regarding the effect mechanism of the sectoral aid-growth nexus through innovative decomposition analysis.

Building hypotheses regarding this research point requires the consideration of two main issues regarding the effect mechanism of aid allocation on their targeted developmental sectors and then growth sectors. Firstly, identifying channels, pathways and conditions through which sectorally-allocated aid might promote developments in its target sectors, and thus, growth sectors and/or growth as a whole, is an econometric challenge. The reason for this is that it is econometrically difficult to distinguish between the respective purposes of different types of aid due to a number of critical issues, the most important of which are the reallocation variation on the part of donors and/or recipient countries (aid volatility and fungibility), as well as the short-term effects of different types of aid (Clemens et al. 2012; McArthur and Sachs 2019). Jones and Tarp (2016) stated that several studies have found aid fungibility and volatility to be high and to likely undermine its effectiveness. Furthermore, a large amount of literature has demonstrated that various types of aid composition can have different fungibility behaviours (Giuliano et al. 2007; Chatterjee et al. 2012; Sethi et al. 2019). While certain aid compositions are non-fungible and linked to public investments, helping promote growth, other aid compositions can be fungible, causing a source of fiscal macroeconomic instability in recipient nations. Therefore, the nature of the allocation of aid to growth sectors is hypothesized to be fungible, volatile and/or transitory.

The second issue to be considered is the donors' unstable financing arrangements of aid allocation across sectors in accordance with the Millennium Development Goals $(\mathrm{MDGs})^{3}$. Considering the fact that economic growth is only one goal of foreign aid, different types of aid allocation across sectors have been changing over time in alignment with attaining MDGs. In this study, we focus on the donors' changeable tendency of aid allocation across sectors that are likely to influence growth. According to Pöntinen (2014), 
different types of aid allocation across sectors have been altered over time due to the MDGs' vision and re-theorizing of aid-growth nexus theories. One of the most intriguing changes in accordance with the MDGs is the shift of aid allocation from other sectors to the social and administrative infrastructure sector, which received the largest share of foreign aid (a total of 38 percent in 2011-2012) at the expense of decreasing aid allocation across other sectors such as economic infrastructure, agriculture and the industrial sector ${ }^{4}$. For example, the industrial sector's overall share fell from 7\% to about 2\% from 1987 to 2012 due to the re-theorizing of the two-gap model (savings-investment-gap). As clarified in the findings of Frot and Santiso (2010), the reason for this is that these investment and funding policies have failed. Therefore, such MDGs' financial re-arrangement of aid across different sectors is ultimately hypothesized to cause heterogeneous effects of aid at the sectoral growth competitiveness level, and the various effects of growth sectors are ultimately hypothesized to impact the whole economy.

This is supported by Feeny and Ouattara (2009), who stated that the influence of growth on poverty is heavily dependent on key growth sectors that promote economic activity, provided that the main purpose of foreign aid programs is arguably poverty alleviation. While some sectors of an economy may be flourishing and fuelling total economic growth, others may be in decline, slowing overall growth. The nature of economic growth might reveal the poverty elasticity of growth. According to Feeny and Ouattara (2009), it is intuitive to state that growth in the agricultural sector will be of the most benefit in terms of poverty alleviation, especially in the SSA region, since the vast majority of the poor in developing countries are positioned in rural areas, depending on agriculture for their livelihoods. Growth in the industrial and service sectors is also significant and can help to drive employment, but it is likely to be less pro-poor than agricultural growth in many countries. Furthermore, with reference to the previous premise, the study pays attention to the effects of donors' changeable tendency of aid allocation across sectors that would only have effects in the short or medium term. Clemens et al. (2012) posit a theoretical base separating "early impact aid" sectors that are expected to support growth in the short-to-medium term; such sectors include roads, energy, agriculture and industry. They are separately categorized from other social and service sectors' activities such as education, health, water and humanitarian assistance, "whose growth effect might arrive far in the future or not at all". Accordingly, the finance re-arrangement of aid across different sectors is also ultimately hypothesized to cause heterogeneous effects of aid on sectoral growth competitiveness level in the short term.

Overall, the preceding discussion concludes that different economic sectors have varying influences on economic growth and development; that is, some economic sectors are more receptive to changes than others. Furthermore, because different types of aid allocation change over time as a result of the MDGs vision and re-theorizing of aid-growth nexus theories, this sectoral imbalance in aid allocation will have differentiated results on targeted sectors, and this type of financing arrangement is ultimately hypothesized to influence the aid effects on overall growth through sectoral growth level, with a prior expectation that the sector with the highest aid allocation will have the highest share of aid estimated effects on overall growth. As such, this study argues that by testing the various responses of growth sectors to their allocated aid, the absence of net effects of total aid on growth can be better explained. In particular, we believe that investigating the various effects of sectoral aid allocation on their corresponding growth sectors will better help explain the aid-growth nexus. The reason is that there exists donors' changeable tendency of financing re-arrangement for aid allocation across developmental sectors over time that are likely to impact growth sectors. This financing re-arrangement for aid allocation across developmental sectors is likely to create heterogeneous variations of sectoral aid effectiveness on their targeted developmental sectors, which will influence their corresponding growth sectors. Such heterogeneous variations of sectoral aid effectiveness may cause fluctuated responses of growth sectors; that is, certain aid allocations may lead 
certain growth sectors to efficiency while leading others to inefficiency. This will affect the sectoral growth's competitiveness and eventually impact the overall economic growth.

In this study, the key questions we intended to address are how and to what extent the heterogeneous impact of sectorally allocated ${ }^{5}$ aid inflows on their corresponding growth sectors (services, agriculture and industry) can affect the recipient countries' economic development and growth. First, we investigated the extent to which MDGs tendency of aid allocation toward different developmental sectors and, thus, growth sectors in recipient countries is predictable (stable) or transitory in nature, and/or fungible, beneficial, or biased in terms of a decomposition analysis of growth sectors and their allocated aid, hypothesizing that aid allocated to the industrial growth sector is more transitory and fungible than other growth sectors. Then, we examined how differences in aid allocation across different sectors in recipient nations affect each sector's growth (sectoral growth competitiveness) and, consequently, overall growth. Hence, the goal was to determine how the link between aid and growth depends on growth sectors' responses to heterogeneous differences in aid allocated to developmental sectors directed toward each of their corresponding growth sectors, hypothesizing that there may be a stronger effect when aid is explicitly targeted at its corresponding growth sectors. As there is no conclusive result in the empirical studies on the foreign aid-growth nexus, this study, with a particular focus on the effects of the sectoral allocation of aid to economic growth sectors, can provide new evidence to reshape policies for both recipients (SSA and MENA in this study) and donor countries. The empirical findings can help improve our understanding of the channels, processes and mechanisms through which foreign aid is used in an economy to achieve economic goals.

This study has the following contributions. First, as clarified above, this was the first study to focus on evaluating the influence of sector-wise allocated foreign aid on the corresponding sectoral growth levels (agriculture, industry and service sectors). Second, the study constructed two measures ${ }^{6}$ of sectoral aid allocated to each growth sector, resulting in a new disaggregation of aid allocated to their respective growth sectors. Third, in contrast to those employing only a single empirical model or strategy, this study used a variety of approaches to check the association between allocated aid on each of growth sectors. In particular, we developed three main specifications to allow the testing all of our hypotheses in our novel decomposition analysis of sectoral growth and its corresponding allocated aid in line with the most related theoretical assumptions and effect mechanism aspects of the aid-growth literature. Finally, the findings that differences in aid's effectiveness among these countries can be explained by looking at differences in growth sector responses are consistent and robust and have important policy implications.

The remaining part of this paper is organized as follows. Section 2 provides a literature review. Section 3 includes a discussion of the models and methodology used in this study. Section 4 discusses the data and empirical results. Sections 5 and 6 provides some concluding remarks, and Section 6 presents the study's limitations and future directions.

\section{Literature Review}

This research relates to the development theory in which foreign aid allocation to specific developmental and/or growth sectors is the foundation for economic progress. Theoretically, the notion of supporting specific growth sectors by foreign aid has been considered in some theories, but the theoretical framework of disaggregating aid across different sectors and thus growth sectors remains unclear. The theoretical debate of these two strands starts with presenting theories supporting specific growth sectors by foreign aid; then, it shows the ambiguity of the theoretical framework regarding the effects of allocated aid across different sectors and, thus, growth sectors.

First, the conception of supporting growth sector level, which is a key notion of the current article, is anchored in some approaches such as structural growth theory (for Lamb 1954; Lewis 1954; Rosenstein-Rodan 1943), a linear-stages-growth approach for Rostow (1960), and the theoretical proposition of Harrod-Domar's growth model on 
channelling foreign aid through mechanisms that are structurally contingent upon growth sector targeting. Rostow (1960) stated that in any economy, there are successive steps of development and modernization; traditional agriculture is turned into contemporary agricultural techniques in the second stage of Rostow's model, which is during the preconditions for take-off phase, and external finance in the form of aid is necessary at this stage. Investment rates begin to rise, resulting in dynamic economic expansion and the obliteration of the primary sector. As noted in Pindiriri (2012), the majority of Sub-Saharan African and Middle Eastern countries are still in the pre-launch phase.

In terms of the second theoretical framework regarding the effects of allocated aid across different sectors and, thus, growth sectors, the allocation of aid across towards growth across multiple developmental sectors has been altered by donors with the goal of achieving the Millennium Development Goals (MDGs), but without adhering to a clear and established theoretical framework for aid allocation channels across developmental sectors and, hence, growth sectors. Notably, due to the MDGs' vision and re-theorizing of aid-growth nexus theories, Pöntinen (2014) revealed trends in the allocation of different types of aid to specific sectors at the expense of other sectors over time. For instance, due to decreasing transaction costs, there has also been a shift in the share of aid for the agricultural and social sectors, decreasing from roughly $13 \%$ to $6 \%$. Moreover, the industrial sector's overall share fell from $7 \%$ to about 2\% from 1987 to 2012; due to the renewed perspectives of the savings-investment-gap model, which is concentrated on the growth theory, Frot and Santiso (2010) clarified that large investment in and financing of the industrial sector has been regarded as a minor project and has gone out of fashion. The challenge here is measuring how such changes in aid allocation across sectors is appropriate from the point of view of the recipient countries. For example, despite sophisticated arguments in favour of a basic human needs approach to foreign aid focused on total growth, according to Aime (2010), a donor allocation bias in favour of social infrastructure over economic infrastructure explains why aid is unproductive in SSA. It is believed that a supply-side bottleneck is a major stumbling block to SSA's development and that failing to resolve this problem renders aid inefficient for crowding in private investments, resulting in Dutch disease.

In conclusion, the changes of aid allocation across sectors based on attaining MDGs and the theories outlined above may have varied outcomes in the recipient's countries. However, none of these changes on the grounds of the theories outlined above provide a clear theoretical link between aid to a given sector and any of the MDG indicators. On the other side, some empirical literature attempted to empirically provide the effects mechanisms of issues at the sectoral level, and they are depicted in their entirety in the next section.

The voluminous empirical studies, with their different strands of pessimism, optimism and middle-ground views, have no clear-cut answer to the question of the foreign aid effect. On the other hand, the scholars who focused on the disaggregated path within the aid-growth literature found degrees of significant positive results depending on the allocation of aid to its respective sectors. Therefore, the current paper presents only the effect mechanisms of empirical studies concerning the disaggregation path within the aid-growth literature. In particular, the two strands of disaggregation path literature that examine sectoral aid on total growth or total aid on sectoral growth.

Previous empirical studies have proposed various mechanisms regarding the disaggregation of aid or growth; these studies are divided into two strands: those that identified the mechanism of how total foreign aid may influence sectoral growth, and those that identified the mechanism of how disaggregated aid can influence total growth. We offer a quick summary of these mechanisms and discuss their implications at the end of this section. Starting with the former strand, they posed the issue of how foreign aid can affect sectoral growth. In this strand, an important contribution to the scholarly debate was made by Feeny and Ouattara (2009), who focus on the premise that total aid efficacy is determined by the types of growth targeted (agricultural growth and industrial growth). 
Feeny and Ouattara (2009) employed data spanning from 1970 to 2001; they used the Generalized Method of Moments (GMM) to subdue the aid endogeneity problem. For modelling, they adopted the same model specifications utilized by the three most influential aid effectiveness studies (Burnside and Dollar 2000; Hansen and Tarp 2001; Dalgaard et al. 2004). Feeny and Ouattara (2009) maintain that the impact of growth on poverty is highly dependent on which sectors of the economy are driving economic activity. As indicated by the poverty elasticity of growth, it is known that growth in the agricultural sector is the type of economic growth that is most beneficial in terms of poverty alleviation, especially in the SSA region, because the vast majority of the poor in developing countries live in rural areas and rely on agriculture for their livelihoods. Industrial and service sector growth is also considerable, particularly in MENA nations, and can drive employment, although it is likely to be less pro-poor in many countries as compared to agricultural growth.

Other researchers in this strand have proposed two additional mechanisms for the overall effects of aid on sectoral growth. The first is connected to the potential drawbacks of aid's macroeconomic effects (Adam and Bevan 2006; Gupta et al. 2006; Selaya and Thiele 2010; Rajan and Subramanian 2011). Selaya and Thiele (2010) estimated the total impact of aid on the tradable sectors (industrial and agricultural growth) and the non-tradable sector (service growth). They employed the GMM method for estimation and adopted model specifications similar to the most prominent studies (Rajan and Subramanian 2008b; Hansen and Tarp 2001; Dalgaard et al. 2004) for a group of 65 developing countries mostly selected from SSA, MENA and South Asian regions, over the period between 1962 and 2001. Adam and Bevan (2006) and Rajan and Subramanian (2011) purely concentrated on the manufacturing sector; Adam and Bevan (2006) relied on highly stylized simulations for the context of low-income countries over a 10-year time period. Rajan and Subramanian (2011) employed a method to make use of the variation across manufacturing sectors within 47 countries and corrected for possible reverse causality for a period spanning from 1980 to 2000. Gupta et al. (2006) designed a tool or a checklist for individual African countries in a time spanning from 1998 to 2003 with macroeconomic scenarios to help scale up the high influx aid flows received by respective African countries. The main point of these studies was centralized in clarifying the extent to which foreign assistance might effectively impede the expansion of productive sectors (exportable sectors) in developing countries. Inflationary pressures and a tendency for local currency appreciation might result from the combination of relatively substantial aid amounts and recipient countries' inability to absorb them. This has a direct and primarily negative impact on the productive sector (agricultural and industrial growth, i.e., the exportable sector) and may have a modulated impact on overall aggregate growth and employment if such effects are sustained over time. Even if donors have promised a significant increase in financial aid to the poorest countries, the likelihood of such impacts may increase.

The overall notion is very similar to the mechanics of the Dutch disease model problem in the aftermath of any form of foreign capital infusion. In an economy producing two types of goods, a large infusion of foreign resources tends to push up the nominal exchange rate, creating a stronger value for the local currency, according to the Dutch disease model (traded and nontraded). Furthermore, the windfall in foreign resources tends to enhance nontraded products' demand, leading to an increase in nontraded goods' prices if there is a scarcity of relatively limited supply, putting downward pressure on local inflation rates. In the scenario where both effects (nominal appreciation and increased local inflation) are obviously combined, the real price of nontraded items rises relative to the price of traded goods. As a result, there are disadvantages in the trading sector's ability to grow, particularly if manufacturing costs and personnel pay are not lowered in that sector. When a long-term slowdown in the traded sector persists, it may slow overall economic growth, especially if significant side effects such as the adoption of new technologies and the opening of new markets occur in the output of tradable sectors. The second mechanism stream of the first strand was carried out by Bräutigam and Knack (2004) and Rajan and Subramanian (2007). Bräutigam and Knack (2004) used the context of 32 SSA countries for 
a period between 1982 and 1997; the study used OLS and 2OLS methods for estimation. Rajan and Subramanian (2007) used the OLS estimation strategy for a period spanning from 1980 to 2000 for the context of all developing countries in the United Nations Industrial Development Organization (UNIDO); they used OLS for estimation and adopted the modelling specification as in Rajan and Zingales (1998). These studies focused on the negative incentives and effects that aid may have on the institutional quality of recipient countries by reducing the pressure to embark on necessary institutional reforms due to the windfall of resources relieving structural deficits for irresponsible fiscal authorities, the tendency of aid to spur corruption and competition for the rents it may create among specialinterest groups, or the phenomena of aid tending to spur corruption and competition for the rents it may create among special-interest groups.

The mechanisms of the second strand are linked to scholars who emphasized the necessity of differentiating between different sorts of aid before evaluating their impact on total growth. This strand of mechanism is divided into two streams. The first stream of the second strand includes scholars who believe that aid transfers that enter the government's budget, through productive financing investments, boost the recipient countries' longterm growth and welfare (see, for instance, Chatterjee et al. 2003, 2012; Chatterjee and Turnovsky 2005; Giuliano et al. 2007). These scholars addressed the challenges of volatility and fungibility. These studies recommended that in order to promote growth, aid should be linked to public investments. These scholars also raised concerns about aid's fungibility and volatility by disaggregating aid to determine the most effective forms of aid in terms of government spending and the degree of fungibility, as well as its effects on growth Indeed, Giuliano et al. (2007) established a theoretical model of aid fungibility and used the GMM method for empirically estimating the aid fungibility of 67 countries, with a majority of these countries being in the SSA, MENA and South Asia regions. The study concluded that the substitution away from domestic government investments was higher than the substitution away from government consumption. This resulted in a drop in domestic productive public spending, essentially cancelling out any growth benefits that aid would have provided. Kharas (2008) used a capital asset pricing model (CAPM) to calculate the deadweight loss from aid volatility in a period spanning from 1970 to 2005 for serval categorical and regional countries including SSA, LAC and EAP countries, lowerincome countries and non-lower-income countries, weak states and strong states, and aid-dependent and aid-independent countries. His work constructed a simple financial metric that policymakers can utilise to check (and reduce) the cost of aid volatility. The author contends that aid volatility is comparable for recipient countries regardless of income level, type of state, degree of aid dependency or geographic location, but it differs by donor, implying that the underlying determinants of aid volatility are the policies of the donors. One of the reasons why impoverished countries have a high ratio of volatility is because aid allocation is biased toward Middle Income Countries (MICs). According to Kharas (2008), aid volatility had a negative impact on output, growth and welfare, with deadweight losses estimated at around US\$16 billion in 2008, accounting for 15 to $20 \%$ of total aid disbursements and $1.9 \%$ of recipient GDP on average.

The work of scholars who outlined that only particular forms of aid should be considered when studying the effect of aid on total growth make up the second mechanism stream of this strand, which includes the work of Clemens et al. 2004, 2012; these empirical studies linked the effectiveness of aid to its core purposes and distribution. Clemens et al. (2004) used OLS and 2OLS to estimate the early impact of aid for selected countries from several regions, including SSA, MENA, Eastern Europe and Asia, for a time period spanning from 1974 to 2001. In their extended version, Clemens et al. (2012) undertook a replication of three of the most cited influential aid-growth studies in the literature (Boone 1996; Burnside and Dollar 2000; Rajan and Subramanian 2008a). They provided two traits of previous studies to help explain the divergence of different studies' conclusions concerning the causal relationship between growth and the timing of aid. According to Clemens et al. (2004, 2012), only certain forms of aid that cause growth should be considered once examining 
the aid-growth nexus; these forms of aid could include aid allocated for the balance-ofpayment support, infrastructure expenditures and support for productive sectors such as agriculture and industry. They labelled it as "early-impact" aid, which boosted growth within four years. Infrastructure financing or the construction of a new road may boost economic activity in the short term. Yet, the effect of a vaccine program may take longer and only lead to the development of growth decades later, and humanitarian relief may never have any influence on growth. As a result, the coefficients of aid may be skewed towards zero due to the inclusion of aid that has no effect. The study indicated that the aid-growth nexus has a favourable average result; however, the findings were questioned by Roodman (2015) and McArthur and Sachs (2019). Roodman (2015) conducted a replication study of Clemens et al. (2012) by replicating their estimation results and then questioning these results with additional specifications and tests; they found that restricting the aid variable to early-impact aid, as proposed by Clemens et al. (2012), makes no significant difference. McArthur and Sachs (2019) took Uganda as a case study for 10 years and designed a model with the aim of establishing a range for scenario building and parameterizations. They found that even among "early impact" pathways and channels, aid allocated to support industry and energy systems might create different structural dynamics from that allocated to agriculture.

This review comes up with three implications. The first implication, based on the findings of scholars who examined the effects of total aid on sectoral growth, is that total aid cannot be considered a homogeneous good. Rather, the impacts of aid are likely to vary depending on the type of aid provided (Jones and Tarp 2016). For example, several studies imply that specific aid allocation programs may be especially important and have varied effects on specific sectors of growth, such as agricultural growth as in McArthur and Sachs (2019), on political institutions (see, for instance, Dietrich and Wright 2012; Gibson et al. 2015; Jones and Tarp 2016; Savun and Tirone 2011) or on a variety of development sectors, including sanitation and social services, gender inequality, education and health (Ferro et al. 2014; Ghimire et al. 2013; Goshu 2014; Ndikumana and Pickbourn 2017; Pickbourn and Ndikumana 2016; Williamson 2008). Empirically, this implies that concentration on aggregate aid flows may be deceptive, according to Jones and Tarp (2016).

The second implication is that the credibility and fungibility of aid are likely to be important. If, for example, aid is largely motivated by donors' short-term strategic objectives, any applicable economic or institutional conditions or putative commitments to long-term economic and institutional development are unlikely to be genuine. As previously stated, empirical data demonstrate that the unpredictability of aid flows has a negative impact on beneficiaries' welfare. According to Celasun and Walliser (2008), aid volatility causes aid expenditures to move from investments to recurrent spending. Furthermore, Kangoye (2013) discovered a correlation between higher aid unpredictability and corruption levels. Aid volatility has a negative impact on output, growth and welfare, with estimated deadweight losses of over US $\$ 16$ billion in 2008, accounting for $15 \%$ to $20 \%$ of all aid disbursements and 1.9\% of recipient GDP on average (Kharas 2008). As a result, this raises our interest in the first specification of our study, to decompose allocated aid inflows directed to each sector of growth into commitment and disbursement datasets to investigate the heterogeneous effects of sectoral commitment and disbursement of allocated aid in terms of sectoral growth.

The third implication is that the reviewed literature does not provide enough theoretical basis and empirical evidence to estimate a straightforward, unidirectional impact of sectorally allocated aid on their corresponding growth sectors; the previously published literature referred only to the effects of sectoral aid on total growth or those of total aid on sectoral growth. However, the current empirical evidence tends to support the view that different aid allocation methods may result in distinct structural dynamics. For instance, McArthur and Sachs (2019) raised the importance of Roodman's (2015) debate regarding the effects of restricting early-impact aid and sectoral aid channel debates, questioning the limited perspective on the actual economic pathways and channels through which aid could 
contribute to growth support, poverty alleviation and structural labour transformation in poor countries toward higher-productivity sectors. Even among "early impact" pathways and channels, they found that the allocated of aid to industry and energy systems may have distinct structural dynamics than the allocation of aid to agriculture. Henceforth, there is a need to conduct a comprehensive analysis of sectorally allocated aid inflows toward each of the growth sectors considering interdependence among growth sectors. Therefore, the current study was undertaken to cover this gap by conducting a SUR investigation of sectorally allocated aid on its corresponding growth sectors.

More recently, several empirical studies attempted to allocate aid to specific growth sectors such as agricultural growth or other developmental sectors such as the health sector, the export sector, services in general or on downstream manufacturing exports, gender inequality, education, democracy, the respect of human rights, the environment and terrorism prevention (see, for instance, Ssozi et al. 2019; Alabi 2014; Norton et al. 1992; Ndikumana and Pickbourn 2017; Ferro et al. 2014; Ghimire et al. 2013; Pickbourn and Ndikumana 2016; Williamson 2008; Findley and Hawkins 2010; Arndt et al. 2014; De Melo and Cadot 2014). For more details about these studies, (refer to Appendix K).

\section{Methodology}

The study modelled three specifications for empirical analysis that progressed in their steps along with the lines and theoretical and empirical framework of the aid-growth literature in order to help answer our core question with its two aspects of focus. As a result, the first specification was modelled to define the first aspect of our question, which was assessing the extent to which aid allocated to various growth sectors is predictable (stable) or transitory in nature and/or fungible, beneficial or biased. This was carried out by operating covariates drawn from the major assumptions of neoclassical and endogenous growth aid-growth models ${ }^{7}$ in our decomposition analysis of sectoral aid on sectoral growth. The second and third specifications were designed to address the second aspect of the study question, which was to determine how the link between aid and growth is influenced by growth sectors' responses to heterogeneous differences in aid allocated to developmental sectors directed toward each of their corresponding growth sectors ${ }^{8}$, using standard aidgrowth literature. This was accomplished by using covariates obtained from the standard literature (see note 8 ) of the aid-growth nexus in order for our decomposition analysis results to be comparable with the standard literature of the aid-growth nexus. In three steps, the theoretical modelling and explanations of the three specifications constructions used for our empirical study are detailed in the rest of this section.

We used three equations in each of the three specifications, with each growth sector serving as the dependent variable (agriculture, industry and service). This study followed Rajan and Subramanian (2008b) and Selaya and Thiele (2010) focusing on the value-added absolute growth (average growth rate) of total GDP for each growth sector in the three specifications rather than growth per worker to analyse the impact of sectoral competitiveness without relying on the strong assumption of constant sectoral employment shares. In the three equations, the allocated aid per growth sector appeared as the corresponding primary regressors for each growth sector. The remaining sets of covariates and explanatory variables were incorporated into the system of equations in accordance with the aims and assumptions of each of the three specifications. The following is the model's initial appearance in the SUR structure:

$$
y_{i j}=x_{i j}^{\prime \prime} \beta_{j}+Z_{i j}+u_{i j}
$$

where: $y_{i j}$ represents growth per sector $j$ (industrial growth, agricultural growth and service growth) for each country $i$, and $x_{i j}^{\prime \prime} \beta_{j}$ represents aid allocated for each corresponding growth sector $j$ in country $i$. $Z_{i j}$ is a vector of covariates for each corresponding $j$ and country $i$, and $u$ is the error term correlated across equations for any given $i$. 
In the first step, we modelled a specification targeting the first concern of the study question, through which we regressed the levels of $S G D P_{i t}{ }^{k}$ sectoral growth (the valueadded of sector $k$ measured as the total value-added GDP for country ' $i$ ' to the rest of the world at time $t$ ) on its respective allocated aid $S A i d_{i t}^{k}$ by using aid commitments and aid disbursements datasets to deal with the possibility of shifts in the donor-recipient relation between the commitment time and when the aid is disbursed (Ghimire et al. 2013); this was also employed to help answer our first concern of heterogeneity. The fungibility and volatility of aid are significant, and are likely to impede its efficacy, according to an extensive literature that has highlighted the donors' bias in aid allocation (see, for instance: Arellano et al. 2009; Bulir and Hamann 2008; Jones and Tarp 2016). As a result, a fundamental decomposition of commitment and disbursement for aid inflows allocated to each sector of growth was employed in this specification in order to differentiate the various effects of sectoral commitment and disbursement of aid on sectoral growth. The rest of the covariates and control variables, specified in this specification, were derived from the neoclassical and endogenous aid-growth models in order to consider their prominent characteristics and assumptions in our decomposition analysis of the impact of sectoral aid on sectoral growth (see, for instance, Ghimire et al. 2013; Goshu 2014; McArthur and Sachs 2019; Nyoni and Bonga 2017; Ssozi et al. 2019). The first specification is illustrated in the following model:

$S G D P_{i t}{ }^{k}=\alpha+\beta_{1} S A i d_{i t}^{k}+\beta_{2} T_{R O} O_{i t}+\beta_{3} P R I V_{i t}+\beta_{4} G S P_{i t}+\beta_{5} S A V_{i t}+\beta_{6} E M P_{i t}+\beta_{7} G O E F_{i t}+\beta_{8} P L S T_{i t}+\alpha_{i}+\varepsilon_{i t}^{k}$

where: SAid stands for aid allocated to industry and agricultural services; the PRIV total private capital flows (net private equity and private debt flow /GDP) ${ }^{9}$ and $S A V$ domestic saving are mobilized as a vector of domestic and foreign capital sources Goshu (2014). TRO trade openness proxied by total exports plus imports/GDP and GSP, government spending measured by general government final consumption expenditure (\% of GDP) is a vector of covariates from economic growth components over the other variables that is used to capture potential side effects of foreign aid, such as 'Dutch-Disease' effects, aid fungibility and other policy variables that are hypothesized to affect growth (see, Goshu 2014; Odusanya et al. 2011 for a review).

According to displacement theory, aid is considered beneficial if it increases savings, public investment and export revenues. The ineffectiveness of this aid was attributed to incompetence in receiving country's fiscal policy, such as aid fungibility ${ }^{10}$, Dutch disease ${ }^{11}$ and aid conditionality ${ }^{12}$ (Xayavong et al. 2005). As a result, these effects are captured using domestic saving, private spending, government spending and trade openness. Private capital was chosen as a proxy for measuring the quality of state investment spending and the existence of development expenditures as described in the study of Makuyana and Odhiambo (2016). As for government spending, Nkusu and Sayek (2004) pointed out that foreign aid, interpreted as a transfer of income to the government, allows for increased public spending, such as public investment, so accounting for it will help in capturing the modulated changes in government spending in response to inflows of allocated aid to growth sectors, as well as identifying the issues of the fungible and non-fungible behavioural aspects of the allocated aid's composition. Openness to trade is thought to boost growth through a variety of avenues, including enhanced access to a wider range of production inputs and access to broader markets, which boost the efficiency of domestic production through higher specialization (Ghimire et al. 2013; Goshu 2014; Nyoni and Bonga 2017; Tait et al. 2015).

The total number of EMP employers (percentage of total employment) was used as a proxy for the labour force to account for aid's effectiveness on workers' moves from lower to higher productivity across sectors of growth (Page and Shimeles 2015). There are two governance indices. The GOEF Government Effectiveness and the PLST Political Stability tests are used to determine the extent to which public institutional quality can enhance or cripple policy efforts. Since the majority of ODA is administered through the government, 
indicators such as government effectiveness and political stability can impede or decide the success of foreign aid and improve the model's explanatory power (Ghimire et al. 2013; Goshu 2014; Nyoni and Bonga 2017; Ssozi et al. 2019; Tait et al. 2015). Table 1, in Section 4, contains more details about all of these variables' measurements and data sources. For more detailed explanations of these variables' definitions, proxies and specifications (refer to Appendix E).

Then, certain variables that may have a specific effect on their corresponding growth sectors were specified for each equation in the whole system of equations, as illustrated in the next extended model of the first specification model; this includes $A L$ (arable lands), $\mathrm{AE}$ (access to electricity for agricultural growth) and UE (the use of energy for industrial growth); as for the service sector, we employed CC (control of corruption) since with ODA being channelled through governments, corruption can mostly choke it through this sector. Then, Equation (2) was extended as,

$$
\begin{gathered}
\mathrm{IND}_{i t}=\delta+\beta_{1} \mathrm{INDaid}_{i t}+\beta_{2} \mathrm{TRO}_{i t}+\beta_{3} P R I V_{i t}+\beta_{4} G S P_{i t}+\beta_{5} S A V_{i t}+\beta_{6} \mathrm{EMP}_{i t}+\beta_{7} G O E F_{i t}+\beta_{8} P L S T_{i t}+\beta_{9} U E_{i t}+\varepsilon_{i t} \\
\mathrm{SER}_{i t}=\gamma+\beta_{1} \text { Seraid }_{i t}+\beta_{2} \mathrm{TRO}_{i t}+\beta_{3} P R I V_{i t}+\beta_{4} \mathrm{GSP}_{i t}+\beta_{5} S A V_{i t}+\beta_{6} \mathrm{EMP}_{i t}+\beta_{7} G O E F_{i t}+\beta_{8} P L S T_{i t}+\beta_{9} C C_{i t}+\varepsilon_{i t} \\
\mathrm{AGR}_{i t}=\sigma+\beta_{1} \text { AGaid }_{i t}+\beta_{2} \mathrm{TRO}_{i t}+\beta_{3} P R I V_{i t}+\beta_{4} G S P_{i t}+\beta_{5} S A V_{i t}+\beta_{6} E M P_{i t}+\beta_{7} G O E F_{i t}+\beta_{8} P L S T_{i t}+\beta_{9} A E_{i t}+\beta_{10} A L_{i t}+\varepsilon_{i t}
\end{gathered}
$$

Bearing in mind the aid endogeneity problem considered in previous literature (Alvi et al. 2008; Dalgaard et al. 2004; Mukherjee and Kizhakethalackal 2013), we instrumented allocated aid in this specification with the best instrumentation method maintained in the literature review, that is, lagging aid by one, two or three periods (i.e., the current period of sectoral growth is regressed on aid lagged by one, two and three periods rather than the aid of the current period) in order to subdue the endogeneity problems. Our results obtained from the robustness check with GMM lagged aid did not differ, and they were the same as those obtained for lagged aid and GMM (refer to Appendices I and J).

In the second step, this study developed a second specification to address the second aspect of the research issue, using the same sort of model but employing "Standard AidGrowth Literature Covariates", a set of covariates that is key to the most prominent studies in the standard aid-growth literature (Boone 1996; Burnside and Dollar 2000; Clemens et al. 2004, 2012; Hansen and Tarp 2001; Rajan and Subramanian 2008a). This approach, involving the employment of the covariates of the most influential prominent studies of the aid-growth literature, has been applied by Feeny and Ouattara (2009) and Selaya and Thiele (2010). In order for the study to be more comparable with the standard aid-growth literature, and to capture the perspectives given in the standard literature regarding our case of sectoral aid-growth decomposition analysis, as well as to address the possibility of variable selection bias, we considered this approach in answering the second aspect of our question. The following empirical model in Equation (6) illustrates the second specification:

$$
S G D P_{i t}{ }^{k}=\alpha+\beta_{1} S A i d_{i t}^{k}+\beta_{2} T P C+\beta_{3} L E_{i t}+\beta_{4} P G_{i t}++\beta_{5} I N C_{i t}+\beta_{6} M S 2_{i t}+\beta_{7} I Q_{i t}++\varepsilon_{i t}^{k}
$$

where: TPC is the share of tropical areas in the country $i$; it is a measure of structural characteristics (Dalgaard et al. 2004; Selaya and Thiele 2010). It is proxied by the share of tropical areas in the country based on Gallup et al. (1999). INC stands for the log of the initial per-capita income; following Rajan and Subramanian (2008b) and Selaya and Thiele (2010), we did not allow sector-specific conditional convergence and drops in initial added sectoral value from the sectoral regressions given the lack of a theoretical basis. Instead, we included initial per-capita income as a control variable in the whole system of equations. The rationale for this was that differences in per-capita income are supposed to be a key factor behind the differences in sectoral growth rates, i.e., structural change ${ }^{13}$. IQ denotes the institutional quality; in this specification, we employed the ICRG index used in Burnside and Dollar (2000) and Rajan and Subramanian (2008a). However, the institutional quality measure in this specification follows the strategy of Rajan and Subramanian (2008a) that was reconstructed in Clemens et al. (2012); it is a metric of 4 indicators including rule of 
law, corruption, bureaucratic quality and democratic accountability ${ }^{14}$. We utilized period averages of the sum of these four indicators of the ICRG index that had been employed in all iterations of the index through the most recent year available. $L E$ represents the log of initial life expectancy to, among other things, capture broader health conditions (Clemens et al. 2004, 2012; Rajan and Subramanian 2008a). Population growth (PG) is proxied by the annual population growth rate; the size of the population functions as a proxy to identify aid allocations due to the fact that larger countries receive relatively less aid per-capita and as a fraction of GDP; this is termed as the small country bias in the allocation literature (Boone 1996; Dalgaard et al. 2004).

MS2 stands for the broad money supply, which is measured by money and quasimoney using (M2) as a \% of GDP, which captures the degree of financial depth and the size of the financial market (Dalgaard et al. 2004; Rajan and Subramanian 2008a; Selaya and Thiele 2010). This covariate is employed to measure the hypotheses that deeper financial markets in aid-recipient countries facilitate the management of aid flows, thereby enhancing aid's effectiveness. It is included in the regressions and lagged by one period to avoid endogeneity problems. More details of the alternative standard control variables measurements and their data sources are provided in Table 1. Detailed explanation of the proxies' definitions and specifications of these covariates are available in Appendix F.

In the third step, we modelled a specification that also targets the second concern of the study question, but in terms of early-impact aid perspective, this specification was constructed to check more direct responses in terms of sectoral growth variation and, thus, provide more interpretation in the short term. On this basis, we re-specified our main independent variable (allocated sectoral aid) on the basis of early-impact-aid as per Clemens's classification of early-impact aid and regressed early-impact aid for respective sectors of growth, utilizing the covariates of the standard aid-growth literature's specifications in order to explore any biased effect of aid on growth sectors that may have responses to early-impact aid, as early-impact aid measures the categories of aid that mainly affect the three growth sectors. This is portrayed in the following model:

$S G D P_{i t}{ }^{k}=\alpha+\beta_{1}$ EarlyAid $_{i t}^{k}+\beta_{2} T P C+\beta_{3} L E_{i t}+\beta_{4} P G_{i t}+\beta_{5} I N C_{i t}+\beta_{6} M 2_{i t}+\beta_{7} I Q_{i t}+\varepsilon_{i t}^{k}$

where: EarlyAid ${ }_{i t}^{k}$ denotes the early impacts of aid. The results of the third specification confirmed the negative impact of allocated aid on the industrial sector. The next part presents the estimation techniques employed in this study.

We employed SUR as the basic estimation method for all specifications and the GMM for robustness tests. Given the dimensions of our sample, the period and the major objective trend (accounting for interdependence among growth sectors) of the current article, our analysis was conducted by employing the SUR technique developed by Zellner (1962). This approach allowed us to jointly estimate the three equations for our sample and helped in considering the interdependence and correlation among sectors of growth, as growth in one sector can be correlated with growth in other sectors and the growth in these sectors is also likely to be affected by common macroeconomic shocks, so the implementation of SUR is expected to produce more efficient estimates than other methods such as equationby-equation analysis. The Breusch and Pagan (1980) test of independence confirmed our expectation and rejected the null hypothesis of zero correlations across sectoral equations, with $p$-values of around 0.000. SUR estimation allows for the serial correlation over panels and permits cross-section error component correlation, i.e., contemporaneous correlation or covariance. Contemporaneous covariance links the disturbances of the several regression equations, and the equations as a set constitute a simultaneous equation system. The equations are linked statistically_albeit not structurally—through the jointness of the distribution of the error terms and through the non-diagonal covariance matrix. Instruments and endogenous statements are not needed for SUR since the SUR method assumes there are no endogenous regressors. However, for a comparative check of robustness, we also ran this specification using GMM, as detailed in Rajan and Subramanian (2008a), where it 
was used as a tool to consider the endogeneity of aid. Our results did not differ; they were the same for lagged aid and GMM.

Table 1. Unit measures and data sources with access link of all variables.

\begin{tabular}{cc}
\hline Variables & Variable Unit Measure \\
\hline Industrial Growth & $\begin{array}{c}\text { Industry (including construction), } \\
\text { value-added growth (annual average } \\
\text { growth rate) }\end{array}$
\end{tabular}

Agriculture, forestry and fishing,

Agricultural Growth value-added growth (annual average growth rate)

Data Sources and Access Link

Data were obtained from World Bank National Accounts data and OECD National Accounts data files. WDI access link https:/ / databank.worldbank.org/reports. aspx? source=world-development-indicators (accessed on 30 November 2018)

Data were obtained from World Bank National Accounts data and OECD National Accounts data files. WDI access link https:/ / databank.worldbank.org/reports. aspx? source=world-development-indicators (accessed on 30 November 2018)

Data were obtained from World Bank National Accounts data and OECD National Accounts data files. WDI access link https:/ / databank.worldbank.org/reports. aspx? source=world-development-indicators (accessed on 30 November 2018)

Service Growth

Sectoral aid allocated to industrial growth
The total of all allocated aid categories (in USD) that primarily affect industrial growth as a \% of GDP.

The product of (the total aid allocated to agricultural growth/GDP) multiplied by 100

Data of numerator includes the total of all allocated aid categories in USD dollars that primarily affect industrial growth in commitments or disbursements datasets; they were obtained from CRS, OECD, https:

/ / stats.oecd.org/Index.aspx?DataSetCode=CRS1\# (accessed on 10 December 2018)

Data of denominator (GDP in current USD) were obtained from WDI

https://databank.worldbank.org/reports.aspx? source $=$ world-development-indicators (accessed on 30 November 2018)

The data of the numerator includes the total of all allocated aid categories in USD that primarily affect agricultural growth in commitments or disbursements;

datasets were obtained from CRS, OECD https:

The total of all allocated aid categories, in USD, that primarily affect agricultural growth as a $\%$ of GDP. agricultural growth

The product of (the total aid allocated to agricultural growth/GDP) by 100

/ / stats.oecd.org/Index.aspx?DataSetCode=CRS1\# (accessed on 10 December 2018)

Data of denominator (GDP in current USD) were obtained from WDI

https: / / databank.worldbank.org/reports.aspx? source $=$ world-development-indicators (accessed on 30 November 2018)

Data of numerator includes the total of all allocated aid categories in USD dollars that primarily affect the growth of the service sector in commitments or disbursements datasets; obtained from CRS, OECD https:

The total of all allocated aid categories in,

Sectoral aid allocated to service growth
USD that primarily affect the growth of the service sector as \% of GDP.

The product of (the total of all aid allocated to service growth/GDP) by 100 .
/ / stats.oecd.org /Index.aspx?DataSetCode=CRS1\# (accessed on 10 December 2018)

Data of denominator (GDP in current USD) were obtained from WDI

https:/ / databank.worldbank.org/reports.aspx? source $=$ world-development-indicators (accessed on 30 November 2018) 
Table 1. Cont.

\begin{tabular}{|c|c|c|}
\hline Variables & Variable Unit Measure & Data Sources and Access Link \\
\hline Early-impact aid (2) & $\begin{array}{l}\text { For the unit measures of early-impact-aid, } \\
\text { we followed the prorating approach of } \\
\text { Clemens et al. (2012). For } \\
\text { early-impact-aid (as a \% of GDP), all data } \\
\text { are in current USD. The numerator for } \\
\text { early-impact aid is the product of gross } \\
\text { ODA (Net ODA + Repayments) and the } \\
\text { ratio of total early-impact ODA } \\
\text { commitments (as classified in Clemens } \\
\text { et al. (2012)) over total ODA } \\
\text { commitments from the CRS. This product } \\
\text { is calculated according to donor-recipient } \\
\text { pairs and then summed across all donors } \\
\text { for a given recipient year. }\end{array}$ & $\begin{array}{l}\text { In \% of GDP. Data of the numerator were obtained from } \\
\text { the Creditor Reporting System (CRS) } 2019 \text { https: } \\
\text { / / stats.oecd.org/Index.aspx?DataSetCode=CRS1\# } \\
\text { (accessed on } 12 \text { March 2019) } \\
\text { and DAC Table2a https: } \\
\text { / / stats.oecd.org/Index.aspx?DataSetCode=CRS1\# } \\
\text { (accessed on 20 March 2019) } \\
\text { The gross ODA (Net ODA + Repayments) were } \\
\text { collected from DAC Table2a } \\
\text { https: } \\
\text { (accessed on 20 March 2019) } \\
\text { / stats.oecd.org/Index.aspx?DataSetCode=CRS1\# } \\
\text { Classified early-impact ODA commitments and total } \\
\text { ODA commitments were obtained from the CRS: https: } \\
\text { / / stats.oecd.org/Index.aspx?DataSetCode=CRS1\# } \\
\text { (accessed on 20 March 2019) }\end{array}$ \\
\hline
\end{tabular}

Following the methodology of Alfaro et al. (2014), we used the most inclusive measure of net private capital flows, which is computed as Net Private Equity/GDP + Private Debt Flows/GDP. The net private equity is computed as Net FDI+ Portf Equity Capital Flows (\% GDP), and private debt flows/GDP is
Private Capita (the most inclusive computed as Net Total Debt from Private Creditors/GDP, which represents the annual changes in the stock of total external debt from private creditors, including private nonguaranteed debt flows, PPG debt flows and private creditors. More details about this measure construction methods are found in "Sovereigns, Upstream Capital Flows and Global Imbalances", Journal of European Economic Association.

Trade openness Total exports plus imports/GDP
The data were obtained from the updated and extended version of the annual panel dataset of net private and public capital flows from the 1970s to 2019 following Alfaro et al.'s (2014) methods. They can be downloaded from

http:/ / sovereign-to-sovereign-flows.com/panel.php (accessed on 20 December 2018)
Data were obtained from WDI

https: / / databank.worldbank.org/reports.aspx? source $=$ world-development-indicators (accessed on 5 January 2019)
Data were obtained from WDI

Employment Employers, total (\% of total employment) https: / / databank.worldbank.org/reports.aspx? source $=$ world-development-indicators (accessed on 5 January 2019)

Data of gross domestic savings, calculated as GDP minus final consumption expenditure (total consumption), were obtained from World Bank National Accounts data, and OECD National Accounts data files World bank

https: / / databank.worldbank.org/reports.aspx? source $=$ world-development-indicators (accessed on 5 January 2019) 
Table 1. Cont.

\begin{tabular}{|c|c|c|}
\hline Variables & Variable Unit Measure & Data Sources and Access Link \\
\hline Government Spending & $\begin{array}{l}\text { General government final consumption } \\
\text { expenditure ( } \% \text { of GDP) }\end{array}$ & $\begin{array}{c}\text { Data were obtained from World Bank National Accounts } \\
\text { data and OECD National Accounts data files } \\
\text { World bank } \\
\text { https:/ / databank.worldbank.org/reports.aspx?dsid= } \\
\text { 2\&series=NE.CON.GOVT.ZS (accessed on 5 January } \\
\text { 2019) } \\
\text { Data for Yemen, Syria, Tunisia and Turkey were } \\
\text { obtained from SESRIC } \\
\text { http:/ / www.sesric.org/baseind-step1-ar.php (accessed } \\
\text { on } 16 \text { January 2019) }\end{array}$ \\
\hline Political stability & $\begin{array}{l}\text { Political Stability and Absence of } \\
\text { Violence/Terrorism: Percentile Rank }\end{array}$ & $\begin{array}{l}\text { Data were obtained from Worldwide Governance } \\
\text { Indicators WGI } \\
\text { http:/ /info.worldbank.org/governance/wgi/ } \\
\text { (accessed on 17 January 2022) }\end{array}$ \\
\hline Government Effectiveness & $\begin{array}{l}\text { Government Effectiveness: Percentile } \\
\text { Rank }\end{array}$ & $\begin{array}{l}\text { Data were obtained from Worldwide Governance } \\
\text { Indicators, WGI } \\
\text { http:/ / info.worldbank.org/governance/wgi/\#reports } \\
\text { (accessed on 10 January 2019) }\end{array}$ \\
\hline Arable land & Arable land (\% of land area). & $\begin{array}{c}\text { Data were obtained from Worldwide Development } \\
\text { Indicators, The World Bank, WDI } \\
\text { https:/ / databank.worldbank.org/reports.aspx? } \\
\text { source=world-development-indicators (accessed on } 5 \\
\text { March 2019) }\end{array}$ \\
\hline Access to Electricity & Access to electricity (\% of population) & $\begin{array}{l}\text { Data obtained from Worldwide Development Indicators, } \\
\text { The World Bank, WDI } \\
\text { https: / / databank.worldbank.org/reports.aspx? } \\
\text { source=world-development-indicators (accessed on } 5 \\
\text { March 2019) }\end{array}$ \\
\hline Use of energy & Energy use of oil equivalent per-capita & $\begin{array}{c}\text { Data were obtained from Worldwide Development } \\
\text { Indicators, The World Bank, WDI } \\
\text { https:// databank.worldbank.org/reports.aspx? } \\
\text { source=world-development-indicators (accessed on } 5 \\
\text { March 2019) }\end{array}$ \\
\hline Control of Corruption & Control of Corruption & $\begin{array}{l}\text { Data were obtained from Worldwide Governance } \\
\text { Indicators, WGI } \\
\text { http:/ /info.worldbank.org/governance/wgi/ } \\
\text { (accessed on 10 January 2019) }\end{array}$ \\
\hline
\end{tabular}

\section{Covariates of the second and third Models}

\begin{tabular}{|c|c|c|}
\hline Tropics & $\begin{array}{l}\text { Geographical tropics, \% land area in } \\
\text { geographical tropics, calculated in } \\
\text { equal-area projection, (Dalgaard et al. } \\
\text { 2004; Gallup et al. 1999) }\end{array}$ & $\begin{array}{l}\text { Data were obtained from Country Geography Data, } \\
\text { indicative of location in tropics, as in Gallup et al. (1999), } \\
\text { https:/ / www.pdx.edu/econ/country-geography-data } \\
\text { (accessed on } 10 \text { April 2019) }\end{array}$ \\
\hline M2/GDP. & $\begin{array}{l}\text { Money and quasi-money (M2) as \% of } \\
\text { GDP, (Rajan and Subramanian 2008a; } \\
\text { Selaya and Thiele 2010; Burnside and } \\
\text { Dollar 2000) }\end{array}$ & $\begin{array}{c}\text { Data were obtained from The World Bank } \\
\text { https:// databank.worldbank.org/reports.aspx? } \\
\text { source=world-development-indicators (accessed on } 15 \\
\text { April 2019) }\end{array}$ \\
\hline Population Growth & $\begin{array}{l}\text { Log population growth (annual } \\
\text { population growth rate), (Boone 1996; } \\
\text { Dalgaard et al. 2004; Burnside and Dollar } \\
\text { 2000) }\end{array}$ & $\begin{array}{c}\text { Data on the annual population growth rate were } \\
\text { obtained from The World Bank WDI } \\
\text { https:/ / databank.worldbank.org/reports.aspx? } \\
\text { source=world-development-indicators (accessed on } 20 \\
\text { April 2019) }\end{array}$ \\
\hline
\end{tabular}


Table 1. Cont.

\begin{tabular}{|c|c|c|}
\hline \multicolumn{3}{|c|}{ Covariates of the second and third Models } \\
\hline Initial life expectancy & $\begin{array}{l}\text { Initial natural logarithm of first } \\
\text { non-missing value in each period of total } \\
\text { life expectancy, (Clemens et al. 2004, 2012; } \\
\text { Rajan and Subramanian 2008a) }\end{array}$ & $\begin{array}{c}\text { Data were obtained from The World Bank WDI } \\
\text { https:// databank.worldbank.org/reports.aspx? } \\
\text { source=world-development-indicators (accessed on } 25 \\
\text { April 2019) }\end{array}$ \\
\hline Institutional quality & $\begin{array}{l}\text { We used period averages of the sum of } 4 \\
\text { components (bureaucratic quality, law } \\
\text { and order, corruption, and democratic } \\
\text { accountability), (Clemens et al. 2004, 2012; } \\
\text { Rajan and Subramanian 2008a) }\end{array}$ & $\begin{array}{l}\text { Data were purchased from the updated version of the } \\
\text { ICRG PRS Group's dataset } \\
\text { https:/ / www.prsgroup.com/explore-our-products / } \\
\text { international-country-risk-guide/ (accessed on } 11 \text { June } \\
\text { 2019) }\end{array}$ \\
\hline Initial per-capita income & $\begin{array}{l}\text { The initial period share of the first } \\
\text { non-missing value in each period of } \\
\text { per-capita income as in (Clemens et al. } \\
\text { 2004, 2012; Rajan and Subramanian } \\
\text { 2008a) }\end{array}$ & $\begin{array}{l}\text { Data were obtained from The World Bank WDI } \\
\text { https:/ / databank.worldbank.org/reports.aspx? } \\
\text { source=world-development-indicators (accessed on } 15 \\
\text { June 2019) }\end{array}$ \\
\hline
\end{tabular}

Note: Author's tabulation.

\section{Results and Discussion}

\subsection{Data Processing}

First, this study used the 'commitment' statistics on aid to examine annual data from 37 Sub-Saharan African and MENA-recipient developing nations classified as low-income, middle-income and upper-middle-income by the World Bank during a 22-year period from 1996 to 2017. In order to account for the departure in the aid commitment data from actual distributions, 'disbursement' aid data were also used, which is available for a 16-year period from 2002 to 2017. In terms of the second and third specifications, this research focused on annual data from 31 SSA and MENA-recipient developing countries over a 22-year period from 1996 to 2017. The 37 countries were reduced to 30 due to the lack of alternative control variable data in the second and third specifications.

We constructed Sectoral Allocated Aid-for-Sectoral Growth (SAASG) measures, which represent aid allocated exclusively for the promotion of its corresponding sectoral growth (agriculture, manufacturing and services). These aid statistics are available from the OECD's Creditor Reporting System in a variety of categories; however, our study used two ways to group these disparate aid categories for the sake of building the first (SAASG) measures. Due to the lack of defined criteria for their design in relation to each of the growth sectors, the current study suggests two feasible Sectoral-Allocated Aid-for-Sectoral Growth (SAASG) measures for each growth sector: The first measure ${ }^{15}$ is based on the potential scope of the effects of certain forms of aid on their corresponding growth sectors (Ghimire et al. 2013). It comprises aid categories that are likely anticipated to have an impact on their respective growth sectors, depending on the effect of their potential scope. This measure is regressed in the first and second specifications. The second measure ${ }^{16}$ is based on Clemens et al.'s (2012) classification of early-impact-aid. This measure contains only the categories of early-impact aid that are expected to influence the sectors of interest, excluding the long-impact or zero-impact subsectors restricted by Clemens et al. (2012). In the third specification, this metric is regressed on the three growth sectors. All variables' definitions, specifications, proxy values and data sources are listed in Appendices E and F. Table 1 provides all the variables' unit measures and data sources with access links.

With regard to the estimation procedures and strategies, we first assessed the statistics features of the variables and then estimated the models using Stata 9 software. After testing summary statistics of all variables for the three specifications, we applied panel unit root testing methods to check the stationarity properties of all variables of the three models by using the IPS test and ADF Fisher-type test. The I(0) shows the stationarity of a variable at a given level, while I(I) presents the stationarity of a variable at the first-difference level. The results showed that all of the variables are stationary at the initial level (refer to 
Appendices $\mathrm{G}$ and $\mathrm{H}$ ) with the exception of political stability and private capitals, which appeared to be stationary at the first-difference level based on the ADF test. The descriptive statistics for all the variables of the specification can be found in Appendices C and D. The summary statistics presented the full sample statistics of the average, standard deviation, mean and range of all variables in all models. The summary statistics of all variables used in the first specifications were obtained first. This comprised 37 cross-sections for 22-time periods, embracing a total of 816 observations. List of the 37 countries are provided in Appendix L. All the variables were used as a percentage of GDP, except the institutional quality variables. Such a methodology was utilized in order to avoid unwanted shocks and mathematical concerns. The descriptive statistics results for the first model's variables showed that all the variables presented normal behaviour, having no outlier in the data series. As for the summary statistics of all variables employed in the second and third models for all countries as a full sample of the study, the panel comprised 30 cross-sections for 22-time periods, embracing a total of 660 observations. All variables were employed in the same manner as that specified in the most influential previous studies. Overall, the results of the descriptive statistics showed the normality of the data, and they did not indicate any presence of outliers in the data. After that, our empirical econometric estimation begun, employing SUR as the basic estimation method for all specifications. The core estimation results and discussion of SUR are presented in the next sub-section.

\subsection{Core Estimation Results and Discussion}

The primary empirical results of sectorally allocated aid against its respective growth sectors are reported in Tables 2-4. Table 2 displays the first specification results of allocated aid against its corresponding growth sectors, addressing the main issue of the first part of the study. The estimated effects for the commitment and disbursement aid datasets are provided in Table 2 . Table 3 shows the second specification outcomes of allocated aid against its respective sectors, using conventional aid-growth literature covariates to address the study's second stage inquiry issue. Table 4 shows the early-impact aid specification for each respective sector of growth, as well as the early-impact aid perspective on the study's second issue.

Table 2. The first specification estimation's results (SUR for both commitments and disbursements).

\begin{tabular}{|c|c|c|c|c|c|c|}
\hline \multirow[b]{2}{*}{$\begin{array}{c}\text { Dependent } \\
\text { Variables }\end{array}$} & \multicolumn{3}{|c|}{ Aid Commitments } & \multicolumn{3}{|c|}{ Aid Disbursements (2002-2017) } \\
\hline & $\begin{array}{l}\text { Industrial } \\
\text { Growth }\end{array}$ & Agricultural Growth & $\begin{array}{l}\text { Service } \\
\text { Growth }\end{array}$ & $\begin{array}{l}\text { Industrial } \\
\text { Growth }\end{array}$ & Agricultural Growth & $\begin{array}{l}\text { Service } \\
\text { Growth }\end{array}$ \\
\hline Sectoral aid & $\begin{array}{c}1.494^{* *} \\
(1.97)\end{array}$ & $\begin{array}{c}2.729 * * * \\
(4.69)\end{array}$ & $\begin{array}{c}-0.180 * * * \\
(-4.64)\end{array}$ & $\begin{array}{l}5.053 \\
(1.31)\end{array}$ & $\begin{array}{c}2.906^{* * *} \\
(3.6)\end{array}$ & $\begin{array}{l}-0.398 * \\
(-1.70)\end{array}$ \\
\hline $\begin{array}{c}\text { Trade } \\
\text { openness }\end{array}$ & $\begin{array}{c}0.078^{* * *} \\
(5.85)\end{array}$ & $\begin{array}{c}-0.051 * * * \\
(-4.02)\end{array}$ & $\begin{array}{l}-0.009 \\
(-0.63)\end{array}$ & $\begin{array}{c}0.097^{* * *} \\
(5.52)\end{array}$ & $\begin{array}{l}-0.048 * * \\
(-2.82)\end{array}$ & $\begin{array}{l}-0.026 \\
(-1.41)\end{array}$ \\
\hline $\begin{array}{l}\text { Domestic } \\
\text { saving }\end{array}$ & $\begin{array}{c}0.576^{* * *} \\
(23.75)\end{array}$ & $\begin{array}{l}-0.295^{* * *} \\
(-13.19)\end{array}$ & $\begin{array}{c}-0.222 * * * \\
(-8.61)\end{array}$ & $\begin{array}{c}0.598^{* * *} \\
(19.89)\end{array}$ & $\begin{array}{c}-0.271^{* * *} \\
(-9.25)\end{array}$ & $\begin{array}{c}-0.226^{* * *} \\
(-7.18)\end{array}$ \\
\hline $\begin{array}{l}\text { Government } \\
\text { spending }\end{array}$ & $\begin{array}{c}0.781 * * * \\
(11.63)\end{array}$ & $\begin{array}{l}-0.665^{* * *} \\
(-10.65)\end{array}$ & $\begin{array}{l}-0.048 \\
(-0.65)\end{array}$ & $\begin{array}{c}0.738^{* * *} \\
(7.19)\end{array}$ & $\begin{array}{c}-0.704^{* * *} \\
(-7.23)\end{array}$ & $\begin{array}{l}0.027 \\
(0.26)\end{array}$ \\
\hline $\begin{array}{l}\text { Government } \\
\text { effective- } \\
\text { ness }\end{array}$ & $\begin{array}{c}-0.246^{* * *} \\
(-8.57)\end{array}$ & $\begin{array}{c}-0.089 * * * \\
(-3.31)\end{array}$ & $\begin{array}{c}0.298^{* * *} \\
(10.14)\end{array}$ & $\begin{array}{c}-0.298^{* * *} \\
(-8.66)\end{array}$ & $\begin{array}{l}-0.037 \\
(-1.08)\end{array}$ & $\begin{array}{c}0.348^{* * *} \\
(10.1)\end{array}$ \\
\hline Employment & $\begin{array}{c}1.067^{* * *} \\
(8.34)\end{array}$ & $\begin{array}{c}-0.751^{* * *} \\
(-6.14)\end{array}$ & $\begin{array}{c}-0.232 * \\
(1.67)\end{array}$ & $\begin{array}{c}1.308^{* * *} \\
(8.33)\end{array}$ & $\begin{array}{c}-0.904^{* * *} \\
(-5.92)\end{array}$ & $\begin{array}{l}-0.335^{*} \\
(-2.07)\end{array}$ \\
\hline Arable land & $\longrightarrow$ & $\begin{array}{c}0.091 \\
1.11\end{array}$ & - & & $\begin{array}{c}0.02 \\
(0.04)\end{array}$ & - \\
\hline
\end{tabular}


Table 2. Cont.

\begin{tabular}{|c|c|c|c|c|c|c|c|c|}
\hline \multirow[b]{2}{*}{$\begin{array}{l}\text { Dependent } \\
\text { Variables }\end{array}$} & \multicolumn{4}{|c|}{ Aid Commitments } & \multicolumn{4}{|c|}{ Aid Disbursements (2002-2017) } \\
\hline & $\begin{array}{l}\text { Industrial } \\
\text { Growth }\end{array}$ & \multicolumn{2}{|c|}{ Agricultural Growth } & $\begin{array}{l}\text { Service } \\
\text { Growth }\end{array}$ & $\begin{array}{l}\text { Industrial } \\
\text { Growth }\end{array}$ & \multicolumn{2}{|c|}{ Agricultural Growth } & $\begin{array}{l}\text { Service } \\
\text { Growth }\end{array}$ \\
\hline $\begin{array}{l}\text { Access to } \\
\text { electricity }\end{array}$ & $\longrightarrow$ & \multicolumn{2}{|c|}{$\begin{array}{c}-0.066^{* * *} \\
(-6.17)\end{array}$} & & - & \multicolumn{2}{|c|}{$\begin{array}{c}-0.063^{* * *} \\
(-4.44)\end{array}$} & \\
\hline $\begin{array}{l}\text { Use of } \\
\text { energy }\end{array}$ & $\begin{array}{l}0.001 \\
(1.44)\end{array}$ & & 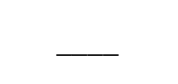 & $\begin{array}{l}0.001 \\
(1.05)\end{array}$ & & & \\
\hline $\begin{array}{l}\text { Control of } \\
\text { corruption }\end{array}$ & 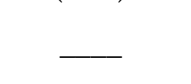 & \multicolumn{2}{|c|}{-} & $\begin{array}{l}-0.001^{* *} \\
(-2.04)\end{array}$ & & & $\begin{array}{l}-1.307 \\
(-1.25)\end{array}$ \\
\hline Political & 0.009 & \multirow{2}{*}{\multicolumn{2}{|c|}{$\begin{array}{l}-0.019 \\
(-0.79)\end{array}$}} & -0.028 & 0.056 & \multirow{2}{*}{\multicolumn{2}{|c|}{$\begin{array}{l}-0.038 \\
(-1.24)\end{array}$}} & $-0.087^{* *}$ \\
\hline stability & $(0.37)$ & & & $(-1.04)$ & $(1.86)$ & & & $(-2.77)$ \\
\hline Private & $0.115^{* *}$ & & -0.018 & 0.087 * & \multicolumn{2}{|c|}{-0.05} & -0.013 \\
\hline capital & $(2.85)$ & & & $(-0.41)$ & $(2.04)$ & \multicolumn{2}{|c|}{$(-1.23)$} & $(-0.30)$ \\
\hline & $3.649 * *$ & \multicolumn{2}{|c|}{$46.203^{* * *}$} & $45.624^{* * *}$ & 1.805 & \multirow{2}{*}{\multicolumn{2}{|c|}{$\begin{array}{c}44.750 * * * \\
(25.72)\end{array}$}} & $46.902 * * *$ \\
\hline Constant & $(2.7)$ & \multicolumn{2}{|c|}{$(33.66)$} & $(29.59)$ & $(1.07)$ & & & $(26.18)$ \\
\hline Observations & & \multicolumn{3}{|c|}{37 countries $(813$ Obs.) } & & \multicolumn{2}{|c|}{37 countries (600 Obs.) } & \\
\hline Adj. R2 & 0.6748 & \multicolumn{2}{|c|}{0.4078} & 0.5889 & 0.6548 & \multicolumn{2}{|c|}{0.4197} & 0.5222 \\
\hline \multirow{4}{*}{$\begin{array}{c}\text { Correlation } \\
\text { matrix of } \\
\text { residuals }\end{array}$} & & Industry & Services & Agriculture & & Industry & Services & Agriculture \\
\hline & Industry & 1.0000 & & & Industry & 1.0000 & & \\
\hline & Services & -0.4683 & 1.0000 & & Services & -0.4201 & 1.0000 & \\
\hline & Agriculture & -0.3173 & -0.4574 & 1.0000 & Agriculture & -0.3705 & -0.4765 & 1.0000 \\
\hline
\end{tabular}

$\begin{gathered}\text { Breusch- } \\ \text { Pagan } \\ \text { test }\end{gathered}$
$290.496^{* * *}$

The dependent variables are agricultural growth, service growth and industrial growth. Coefficient estimates are noted as significant at $1 \%\left({ }^{* *}\right), 5 \%\left(^{* *}\right)$ and $10 \%(*)$ levels. Values in parentheses are $\mathrm{z}$ values. Sectoral aid represents the aid for industry, agriculture and services, the three corresponding sectors of growth.

Table 3. Estimation results for the second specification (standard aid-growth covariates).

\begin{tabular}{|c|c|c|c|}
\hline \multirow[b]{2}{*}{ Dependent Variables } & \multicolumn{3}{|c|}{ Aid Commitments } \\
\hline & Industrial Growth & Service Growth & Agricultural Growth \\
\hline $\begin{array}{c}\text { Sectoral aid } \\
\text { (before lagging M2) }\end{array}$ & $\begin{array}{l}-0.874 \\
(-0.39)\end{array}$ & $\begin{array}{l}0.067^{* *} \\
(0.025)\end{array}$ & $\begin{array}{l}3.055^{* * *} \\
4.75\end{array}$ \\
\hline $\begin{array}{l}\text { Sectoral aid after lag M2 } \\
\text { (Main Specification) }\end{array}$ & $\begin{array}{l}-5.070 * * \\
(-2.46)\end{array}$ & $\begin{array}{l}-0.068 * \\
(-1.80)\end{array}$ & $\begin{array}{l}2.921^{* * *} \\
-4.55\end{array}$ \\
\hline $\begin{array}{l}\text { Aid*lagged financial depth M2 } \\
\text { (Average) }\end{array}$ & $\begin{array}{c}-4.486 \\
4.507\end{array}$ & $\begin{array}{l}-0.0799 * * \\
0.038\end{array}$ & $\begin{array}{c}-0.760 \\
0.550\end{array}$ \\
\hline Aid*intuitional quality & $\begin{array}{c}0.973 \\
0.54\end{array}$ & $\begin{array}{l}-0.059 * * * \\
-4.08\end{array}$ & $\begin{array}{l}0.147 \\
0.651\end{array}$ \\
\hline $\begin{array}{c}\text { Aid*tropics } \\
\text { (dummy level) }\end{array}$ & $\begin{array}{l}-6.544^{* *} \\
-2.52\end{array}$ & $\begin{array}{l}-0.674^{* * *} \\
-3.68\end{array}$ & $\begin{array}{l}4.522^{* * *} \\
6.04\end{array}$ \\
\hline Tropics & $\begin{array}{l}2.238^{* * *} \\
-7.63\end{array}$ & $\begin{array}{l}-0.271 \\
(-1.49)\end{array}$ & $\begin{array}{l}-1.322 * * * \\
(-5.67)\end{array}$ \\
\hline Institutional quality & $\begin{array}{l}0.859 * \\
-2.49\end{array}$ & $\begin{array}{l}1.085^{* * *} \\
5.12\end{array}$ & $\begin{array}{l}-1.923^{* * *} \\
(-7.23)\end{array}$ \\
\hline Initial life expectancy & $\begin{array}{l}0.577^{* * *} \\
5\end{array}$ & $\begin{array}{l}-0.654^{* * *} \\
(-9.10)\end{array}$ & $\begin{array}{l}-0.171 \\
(-1.92)\end{array}$ \\
\hline Initial per-capita Income & $\begin{array}{c}-19.516^{* * *} \\
(-13.68)\end{array}$ & $\begin{array}{l}8.756^{* * *} \\
9.98\end{array}$ & $\begin{array}{c}8.660^{* * *} \\
7.91\end{array}$ \\
\hline Population growth & $\begin{array}{c}-6.101^{* * *} \\
(-3.85)\end{array}$ & $\begin{array}{c}4.648^{* * *} \\
4.77\end{array}$ & $\begin{array}{c}2.723 \text { * } \\
2.24\end{array}$ \\
\hline
\end{tabular}


Table 3. Cont.

\begin{tabular}{|c|c|c|c|c|}
\hline \multirow[b]{2}{*}{ Dependent Variables } & \multicolumn{4}{|c|}{ Aid Commitments } \\
\hline & Industrial Growth & \multicolumn{2}{|c|}{ Service Growth } & Agricultural Growth \\
\hline Lagged M2/GDP & $-0.051^{* * *}$ & \multicolumn{2}{|c|}{$0.037^{* * *}$} & $0.023^{* *}$ \\
\hline Lagged financial depth & $(-4.39)$ & \multicolumn{2}{|c|}{5.28} & 2.61 \\
\hline \multirow{2}{*}{ Constant } & $105.154^{* * *}$ & \multirow{2}{*}{\multicolumn{2}{|c|}{$\begin{array}{c}7.368 \\
1.01\end{array}$}} & -3.662 \\
\hline & 9.05 & & & $(-0.41)$ \\
\hline Observations and countries & \multicolumn{4}{|c|}{30 countries ( 660 Obs.) } \\
\hline Adj. R2 & 0.5043 & \multicolumn{2}{|c|}{0.4788} & 0.3223 \\
\hline \multirow{4}{*}{$\begin{array}{l}\text { Correlation matrix of } \\
\text { residuals }\end{array}$} & & Industry & Services & Agriculture \\
\hline & Industry & 1.0000 & & \\
\hline & Services & -0.2505 & 1.0000 & \\
\hline & Agriculture & -0.5951 & -0.2820 & 1.0000 \\
\hline Breusch-Pagan test & \multicolumn{4}{|c|}{$308.784^{* * *}$} \\
\hline
\end{tabular}

The dependent variables are agricultural growth, service growth, and industrial growth. Coefficient estimates are noted as significant at $1 \%\left({ }^{* * *}\right), 5 \%\left({ }^{* *}\right)$ and $10 \%\left({ }^{*}\right)$ levels. Values in parentheses are $\mathrm{z}$ values. Sectoral aid represents the aid for industry, agriculture and services, the three corresponding sectors of growth. For the average of interaction term effect, Standard Errors are between brackets.

Table 4. Empirical estimations of early-impact aid specification.

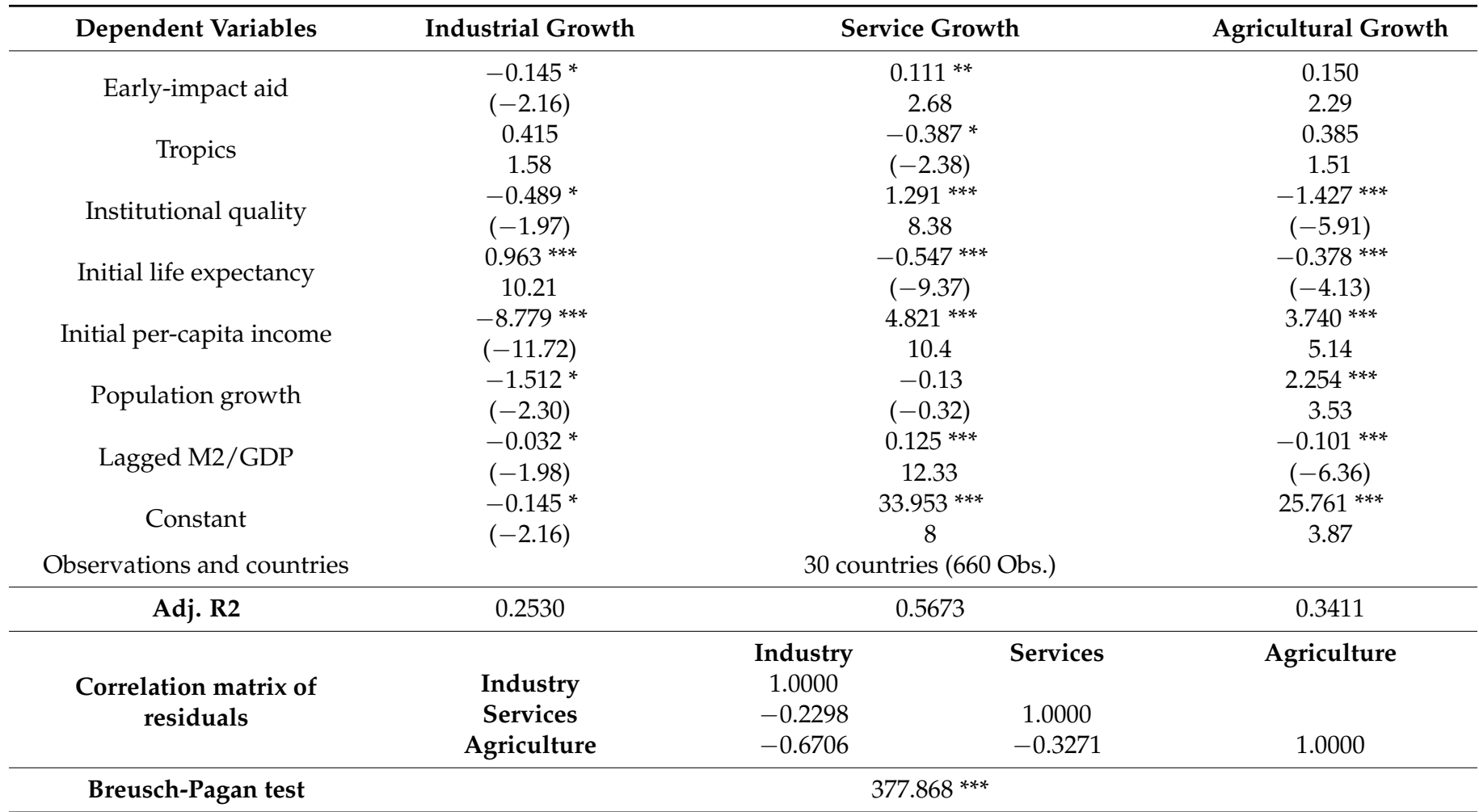

The dependent variables are agricultural growth, service growth and industrial growth. Coefficient estimates are noted as significant at $1 \%\left({ }^{* * *}\right), 5 \%\left({ }^{* *}\right)$ and $10 \%\left({ }^{*}\right)$ levels. Values in parentheses are $\mathrm{z}$ values. Sectoral aid represents the aid for industry, agriculture and services, the three corresponding growth sectors. Repayment was omitted due to collinearity.

\subsubsection{The First Specification Estimation's Results and Discussion}

Table 2 shows that the regression results regarding the allocation of aid to industrial growth support positive and substantial estimated coefficients in commitment datasets but insignificant results in aid disbursements datasets. The regression results for the growth of the service sector reported negative and highly significant estimated coefficients in both 
datasets. In both regressions (the industrial growth and service growth regressions), the estimated coefficients' results for the composition of allocated aid inflows and their related covariates in terms of their corresponding growth sectors showed similar behavioural aspects for the fungible and non-fungible aid of aid-recipient economies.

The industrial growth regression results of aid commitments (as shown in the first column) confirmed the non-fungible behavioural aspects of the composition of aid allocated to industry in terms of the corresponding industrial growth. Such non-fungible behaviours in the composition of the allocation of industrial aid in terms of the corresponding industrial growth were illustrated by all the positive coefficients for all covariates, namely private capital, government expenditure, domestic saving and employment. Government expenditure, private capital, domestic saving and other factors exhibited positive coefficients when receiving aid inflows for industrial growth. This implies that with an influx of aid allocated to industrial growth, the increasing of resources devoted to public investment products (given the positive coefficient of private capital, domestic saving, government spending and so on) boosts private capital productivity, resulting in higher private capital accumulation and industrial growth rates.

These findings showed that the allocation-parameter proportion of investment aid in the commitment dataset was higher than the allocation-parameter proportion of consumption aid. This is consistent with much of the mainstream theoretical literature on this subject, such as Giuliano et al. (2007) and Chatterjee et al. (2012). The positive coefficients for trade openness and employment showed that access to bigger markets increased the efficiency of domestic production through higher specialization.

However, the coefficient sign of the composition of aid allocated to industry in the disbursement dataset was insignificant, implying no actual influence and corroborating our prediction that aid allocated to industrial growth is more transitory and fungible than other growth sectors. The results of lagged aid and GMM, provided in Appendices I and J, confirmed the exact inference. This could have been due to a government effectiveness problem and/or a lack of government policies to handle these types of industrial growth aid; it could also be due to the shorter disbursement period dataset.

On the other hand, the regression results regarding the growth of the service sector for both datasets in columns (3) and (6) showed fungible behavioural aspects regarding the composition of the aid allocated to services in relation the corresponding growth of the service sector. The coefficients of the variables of the service growth regression revealed no significant responsive effects of private capital and government spending, while other covariates such as domestic saving, employment and corruption showed a significant negative contribution to the growth of the service sector. These results reflect the fungible behaviours of the composition of aid allocated to service growth, where domestic spending on the public investment goods declines in proportion to the composition of aid inflows assigned to service growth (given the negative effect of domestic saving and the insignificant effect of private capital and government spending). This implies that aid earmarked for investment is merely a substitute for domestic investment spending, crowding domestic saving and resulting in more fungible behaviour, indicated by corruption. Such a process, in return, dominates the negative effect on the growth of the service sector as a whole. Similar results were documented in the works of Gupta et al. (2003) in the context of 137 developing economies and Pack et al. (1993) for the case of the Dominican Republic. In the African countries context, Collier (2007) and Whiteside (2010) also argued that the failure of foreign aid's effectiveness in Africa was due to corruption.

In terms of the estimated effects of sectorally allocated aid on agricultural growth, it is clear that the allocation of aid with a highly positive coefficient has a highly positive impact on agricultural growth. However, in both the commitments and disbursements datasets, practically all explanatory variables produced negative and statistically significant estimated coefficients, with the exception of political stability. This could be due to crosssector crowding-out effects, as well as a substitution effect between domestic farmers and imports from other countries. If these effects are dominant, an increase in aid in one area 
may result in a decrease in other investments, such as more imports at the expense of lower domestic output. The findings revealed that, while agricultural aid has a positive estimated influence on agricultural growth, it drowns out domestic saving and other economic indicators. This is consistent with Basnet's (2013) argument regarding South Asian countries (Bangladesh, India, Nepal, Pakistan and Sri Lanka), namely that while boosting GDP, foreign aid crowds out local savings.

To summarize, the results of the first specification showed that the allocation of aid to growth sectors can also be transitory and that these allocations can be fungible in one growth sector while being non-fungible in another. In comparison to previous research findings, which looked at either the homogeneous effects of aggregate aid on sectoral growth or the heterogeneous effects of sectoral aid on total growth, our results, in terms of sectoral decomposition analysis, suggested more explanations, effect mechanisms and channels for the fungibility issue in terms of the competitiveness of sectoral growth. These findings sketched a further detailed picture of the fungibility problem, identifying the fungible and non-fungible behaviour based on the exact composition of sectorally allocated aid in each growth sector, which can obscure the total net influence of aid on overall growth. Other research findings demonstrated how aid fungibility problems can directly conceal the effect of aid on overall growth without considering sectoral competitiveness. Examples of these studies include the works of Giuliano et al. (2007) and Chatterjee et al. (2012) conducted in the context of 67 developing countries mostly selected from the SSA, MENA and South Asia regions, and that of Chatterjee et al. (2003), which focused on 56 developing countries.

\subsubsection{The Second Specification Estimation's Results and Discussion}

The findings of this specification's estimations showed how diverse changes in aid allocation to different development sectors in recipient nations create variations of responses in each sector of growth and, thus, influence the competitiveness of sectoral growth. The regression results of the second specification, shown in Table 3, showed how the relationship between aid and growth is influenced by differences in aid allocated to the growth sector. As shown in the first row of Table 3, the initial responses of growth sectors to their allocated aid with the new specification covariates showed a direct positive behavioural effect for all growth sectors except industrial growth, but after controlling for the depth of the financial market with lagged M2, the results' signs completely changed. As indicated in the second row of Table 2, the growth responses of the industrial and service sectors to their allocated aid became sharply negative, but agricultural growth preserved its positive statistical significance. This could indicate a lack of financial market depth management and capacity absorption in these countries, where financial market depth has an impact on a country's ability to absorb aid inflows in a way that may induce and/or conceal the overall effect of allocated aid inflows on recipient growth sectors and goes beyond its direct effect. To confirm this intuition and evaluate the relevance of aid's interaction with financial market depth, we followed Nkusu and Sayek (2004) and tested the hypothesis that deeper financial markets facilitate such management, and improve the overall effect of aid on growth.

The conditional estimated effects results of the aid and financial market depth interaction term confirmed the importance of the development of financial markets in terms of absorbing the recipient nations' capacity to successfully invest the allocated aid inflows into the growth of the service sector. The findings of the service-growth equation in row 3 , column 2 showed that the greater the financial lag, the less effect the allocated assistance has, validating the hypothesis that there are inadequate systems to manage local financial market depth, which reduces allocated aid's effectiveness in terms of the growth of the service sector. As a result, these findings showed that the depth of the financial market does not help manage aid flows to growing service sectors in the MENA and SSA countries. This implies that the local financial market depth is one of the essential factors that mitigates the direct effects of aid in these countries. These findings are in line with the results of Nkusu and Sayek (2004) obtained for 86 developing countries mainly selected from the 
SSA, MENA and South Asian regions, and those of Sethi et al. (2019), which focused on India and Sri Lanka. Both studies found that the more developed the receiving country's financial system is, the more effective the aid is, and vice versa. In conclusion, our findings in this regard make it possible to determine that the effects of the allocation of aid to the growth of services are hampered by weak financial market management, which mitigates the effects of the allocated aid in terms of the competitiveness of sectoral growth. Thus, these effects mask the net effects of total aid on total growth.

As for the interaction between allocated aid and institutional quality, the findings reveal that the impact of allocated aid on agricultural and industrial growth is not conditional on institutional quality. These findings are consistent with those of Rajan and Subramanian (2008a), who found a non-conditional association between the aid and institutional quality interaction term and industrial sector growth in 47 developing countries mainly selected from the SSA and MENA regions. Our findings are also in line with Selaya and Thiele (2010), who found an insignificant association between aid and institutional quality interaction term and the growth of each of the sectors in the context of 65 developing countries primarily selected from the SSA, MENA and South Asia. However, the efficiency of aid allocated to the growth of services is found to be mitigated by the poor performance of institutional quality. This implies that poor bureaucracies and democratic policies, and a lack of partiality in legal and political systems undermine the effectiveness of aid allocated to the growth of the service sector, posing a threat to foreign aid investment and reducing the efficiency of this sector's response. Such findings make it possible to determine composition of the aid allocated to the growth of services as the specific sector that suffers from poor institutional quality indicators, which validates the rationale for the sector's poor financial market system management.

With regard to the findings of the aid and tropical areas interaction term, the results of this specification provide further important insights regarding the effects of allocated aid on the growth of its corresponding sectors. The interaction term results showed highly negative estimated effects of allocated aid on industrial- and service-sector growth in countries located in more tropical areas, whereas the estimated effects on agricultural growth showed highly significant positive effects in countries located in more tropical areas. That is, in countries in more tropical areas, aid exerts a sharply positive trend in terms of having higher rates of impact on agricultural sector growth. The findings indicate that aid inflows into most MENA and SSA nations are more productive for agricultural growth and that they are particularly high in countries in more tropical areas. The highly significant estimated coefficients for countries in more tropical areas could be interpreted with reference to the fact that countries located in more tropical areas receive more aid because of their disadvantageous locations and climates; this fact was previously stated in the findings of Dalgaard et al. (2004) in the context of all developing countries and by Selaya and Thiele (2010) for a group of 65 developing countries. Furthermore, based on the results for the aid and tropical areas interaction term, this study can conclude that regarding countries located in more tropical areas, allocated aid investments are being directed and absorbed by agricultural growth in order to improve productivity ${ }^{17}$, but at the cost of reducing the effectiveness of aid allocated to industrial and service growth, which in return conceals the effects of total aid flows on the total GDP in countries located in more tropical areas. As a result, the findings may help in furthering the interpretation of the mechanism of effects regarding the findings of Dalgaard et al. (2004) and Selaya and Thiele (2010). This study clarifies that the effectiveness of total aid flows on total GDP is lower in countries located in more tropical areas due to the variations in the effects sectoral aid across different sectors in terms of their growth (increasing agricultural growth but decreasing growth in other sectors).

Finally, the results of the second specification support the hypothesis of the second aspect of concern in this study, namely that the link between aid and growth is dependent on responses to homogenous differences in aid distributed to each of the respective sectors undergoing growth. The estimation results showed how differences in the growth-related 
responses to the composition of aid allocated to different sectors help to reduce the effects of total aid on overall growth. The specification also revealed which factors can mask or amplify the effects of disparities in aid distribution on sectoral growth and, as a result, the total impact of aid on overall growth. This specification revealed the poor performance in the growth of the service sector and provided more explanations for and factors underpinning that, such as the depth of financial markets and institutional quality. It also showed some factors that contributed to the positive performance of agricultural-growth aid, such as the location of the country within tropical areas. On the other hand, industrial growth showed either negative or insignificant direct responses in practically all conditional terms. This means that aid earmarked for industrial growth is not helping to boost industrial growth, which lowers the overall impact of aid.

In comparison to prior study results, our estimation results obtained using the sectoral decomposition analysis methodology provide further interpretations and possible mechanisms explaining the effects of common interaction factors including tropical area, financial depth and institutional quality. For example, for all direct situations and tropical conditions, the results showed strong rates of growth generated by aid dedicated to agricultural growth, providing more context for prior findings on the tropical areas issue. Unlike Dalgaard et al. (2004) and Selaya and Thiele (2010), who concluded that the effectiveness of total aid flows on total GDP is lower in countries located in more tropical areas due to disadvantageous locations and climates, our findings showed a further interpretation of how disadvantageous locations and climates can reduce the positive effects of aid, namely through the variation of the effects of sectoral aid among growth sectors. Furthermore, while previous research identified poor financial system management and institutional quality as factors that limit overall growth, our findings pinpoint the exact area of sectoral growth and aid composition behind the poor financial market management that occurred when aid was received in selected MENA and SSA countries. Our results revealed that the composition of the aid allocated to the growth of the service sector caused poor management of the financial markets related to this sector due to fact that sudden influxes of aid allocated to this sector were received; the results also showed that the composition of aid allocated to the growth of services decreased institutional-quality performance.

\subsubsection{The Third Specification Estimation's Results and Discussion}

By estimating the effects of early-impact aid on each growth sector, the results for the third estimation revealed how various changes in aid allocation to different development sectors in recipient nations may cause variations in responses between each sector of growth in the short term, thus influencing the competitiveness of sectoral growth. This study considered the perspective of early-impact aid to provide a more precise evaluation of the varied growth-related responses to aid across sectors in the short term. Consideration of the early-impact assistance specification may allow for more direct coefficient results for growth sectors since these sorts of aid are more likely to exert effects in the short term and would not bias the aid coefficient towards zero (Clemens et al. 2004, 2012).

In conclusion, the specification results concerning the variation in the responses of each growth sector to the early-impact aid they received are consistent with the second set of specification results. As with the second set of specification results, these results explained the absence of the effect of total aid on growth by showing the variation in the effects on the competitiveness of sectoral growth. In other words, these results found that industrial growth negatively responds to early-impact aid, whereas the growth of services responds insignificantly to early-impact aid, implying that these sectors mitigate the net effects of total aid on total growth. 
To summarize, the findings for the three empirical core specifications support the study's two main points of attention. As shown in the first model specification, the analysis revealed the fungible and non-fungible behaviour of the composition of aid allocated to each growth sector in terms of sectoral decomposition. The study then explained how the net effect of total aid on total growth was mitigated by the different responses of growth sectors to heterogeneous differences in their allocated aid compositions, highlighting specific issues and factors in each of the growth sectors that weakened the competitiveness of sectoral growth and, thus, weakened overall growth. The findings showed that in all three specifications and under all tropical conditions with accelerated growth rates, the agricultural sector had a direct, significant and positive response to its aid allocation, implying that aid to this sector is effective in improving the agricultural sector and the competitiveness of sectoral growth in this area. In the first specification, the industrial sector displayed only one positive reaction in the commitment dataset but insignificant responses in the disbursement dataset. In the second specification, all responses of industrial growth were insignificant for all conditional factors. In the second and third specifications, aid allocated to industrial growth was more likely to deteriorate in response to allocated aid inflows in the MENA and SSA regions, implying that responses of the industrial growth sector attenuated the net effect of overall aid on growth. The service sector's overall pattern of response tended to be negative, notably in relation to the first and second main specifications and under the condition of financial system depth, showing that aid given with the aim of creating growth in the service sector and, therefore, increasing the competitiveness of sectoral growth in this area, is inefficient.

While this study used a different sample and time period, as well as more appropriate methodologies and measures for its objective, our findings are consistent with those of other empirical studies that have looked at different sectors of growth; the results obtained for the agricultural sector consistent with those regarding the growth of other sectors (Feeny and Ouattara 2009; McArthur and Sachs 2019; Ssozi et al. 2019). The results of obtained for the industrial sector are consistent with Feeny and Ouattara (2009), who found a weak response of the industrial sector. However, they contradict Selaya and Thiele (2010), who confirmed that the industrial sector is unlikely to deteriorate in response to an inflow of foreign aid and that tradable sectors have no external competitiveness (industry and agriculture). Moreover, our findings for the service sector are not consistent with the findings of Ferro et al. (2014), who reported a positive effect of aid on services in general, as well as downstream effects on the manufacturing of exports, in developing nations across geographical regions and income categories. Our findings are novel in that they provide more precise and efficient results that highlight the efficiency and weaknesses of each response of each growth sector to its allocated aid under a variety of model specifications and conditions, considering the interconnectedness of growth sectors.

\section{Conclusions and Implications}

Our main point of contention is that the heterogeneous effects of sectoral aid on its targeted developmental sectors, and thus overall growth, can be better explained by looking at how different types of growth sectors respond to their respective heterogeneously allocated aid inflows and taking into account two concerns about heterogeneity. The first involves exploring the extent to which the tendency of aid allocation toward different developmental sectors and growth sectors in recipient countries is predictable (stable), transitory, and/or fungible, beneficial or biased in terms of a decomposition analysis of growth sectors and their allocated aid. This is taken into account to identify the responses of different growth sectors to their corresponding allocated aid inflows and, as a result, sketch the inner image of sectors' growth responses to their corresponding allocations of aid. The second concern about heterogeneity relates to determining whether and how the link between aid and growth is influenced by the growth sectors' responses to heterogeneous differences in the aid allocations they receive from developmental sectors that are directed toward these corresponding growth sectors, and it is hypothesised that there may be a stronger effect 
when the allocated aid is explicitly targeted to its corresponding growth sectors, as these targeted allocations are thought to specify the most responsive and important growth sectors.

As a result, the study empirically examined the impact of allocated aid on sectoral growth (industrial, agricultural and service sector growth) in the MENA and SSA areas. The evidence was based on a sectoral decomposition of the effects of allocated aid on its respective growth sectors, which was conducted using the SUR approach to account for interdependence and inter-correlation among growth sectors; the GMM was also used for robustness. We modelled three typical aid-growth econometric specifications to account for the two main concerns of the study and allow the employing of derived covariates related to each of the two main hypotheses, as well as the models of assumptions from the aidgrowth literature (neoclassical and endogenous assumptions and the standard literature assumption models), which were considered in order for the study to be comparable to previous literature and to control for variable-selection bias in our case. Different specifications, analytic approaches, conditioning factors, data, metrics and endogenous characteristics of aid disbursements proved to have a robust positive impact on the outcomes.

Our major findings showed that aid allocated for each sector of growth has clear systematic impacts, which helps to explain why the net effect of total aid on total growth appears to be insignificant in terms of overall growth. These findings supported our main argument of the article, namely that the aid-growth nexus can be better grasped by examining the responses of various growth sectors among these nations to their corresponding allocations of aid. Considering various flaws and factors in each specification, we could come up with a possible explanation for our findings. As shown in the initial model specification results, the study first determined the allocated aid compositions' fungible and non-fungible behaviours for each growth sector in terms of sectoral decomposition. The study then explained how the net effect of total aid on total growth is mitigated by the various responses of growth sectors to the heterogeneous differences in the compositions of their allocated aid, highlighting specific issues and factors in each of the growth sectors that weaken the competitiveness of sectoral growth as well as overall growth. The study argued that the modulated effects of the allocation of aid to growth sectors are contingent on certain conditional economic, environmental and institutional characteristics and elements, including the depth of financial markets, tropical location and institutional quality, with the case for this being made in the results for the second model specification. For example, in MENA and SSA countries, the direct effects of the allocation of aid in terms of the competitiveness in the growth of corresponding sectors, and thus, economic growth in general are mitigated due to the poor management of the financial systems related to the growth of the sector, which is caused by the negative effects of the institutional quality in this sector. The study also concluded that industrial growth reacts negatively in many specifications, owing to inadequate industrial processes in the MENA and SSA regions. As a result, this negative growth response is a component that helps conceal the net benefits of total aid on growth. In comparison, the environmental factor of tropical location in relation to aid was found to improve agricultural development and thus overall growth.

\section{Policy Implications}

The empirical findings are ground-breaking and have a number of policy consequences. Our decomposition investigation offers further interpretations, channels and impact mechanisms relating to the aid-growth nexus and brings to light some difficulties such as the negative impact of aid in more tropical locations, financial depth and institutional quality. As a result, these results reveal issues that help identify how aid inflows could be spent and invested appropriately on targeted growth sectors by revealing the weak and efficient areas of sectoral aid on growth sectors. According to these findings, the effectiveness of aid in MENA and SSA nations is dependent on improving the financial and monetary systems, as well as institutional quality policies, in order to develop the growth of services in recipient countries. In addition, these countries must devise a strategy for maintaining incentives 
to overcome structural bottlenecks in growth sectors. Significant efforts will be required to effectively invest allocated aid in order to improve the poor performance of industrial growth in countries of both regions. Scaling up foreign aid in conformity with study's findings may thus help in the achievement of the MDGs for both SSA and MEAN nations. Furthermore, it is critical for donors to support growth in industrial sectors and authorize strategies to re-theorize aid allocated to the industrial sector, particularly in the current technological age in both regions. Based on the study's findings, each recipient country should prioritize aid for industrial sectors. Agriculture and the service industry, on the other hand, will frequently need to be targeted. Finally, the responses of the growth sectors to their allocated aid present discoveries that invite precise further consideration, as they indicate that sectoral-aid-for-growth can be used as a heuristic policy variable in the study of sectoral growth behaviour.

\section{Limitations and Future Directions}

The current study provides interesting and innovative findings and offers useful, practical implications on how to retain the efficiency of aid in terms of its effects on sectoral growth to allow for better economic progress. However, there are a few limitations with the current study. Firstly, the study was conducted on only 37 selected countries from the SSA and MENA regions due to the lack of data for some variables in some countries in these regions. In addition, the size of our sample was restricted to 31 countries in the second set of model specifications due to the unavailability of data on some important institutional and tropical factors such as democratic accountability, civil wars, civil society funding, and internal and external conflicts for the six excluded countries.

With regard to future research, our study highlights that the sectoral decomposition analysis of aid and growth can be extended by engaging more factors, countries and considerations, such as by conducting analyses of levels of income across regions to observe the regional heterogeneity. In addition, scholars are advised to measure the impact of sectoral aid inflows on the structure of imports and exports. Furthermore, the role of sectoral aid inflows to civil society, the military and NGO can also be discovered with respect to the alleviation of terrorism and economic progress. Other derived future research based on our decomposition approach could involve the conducting of an empirical analysis of the impact of Chinese and Japanese sectoral foreign aid in terms of sectoral growth in SubSaharan African and MENA countries. Future research can also be conducted using newly developed panel data techniques such as spatial or spillover methodologies and panel smooth transition autoregression models (PSTR), which can also capture asymmetric and non-linear effects. Finally, conducting this analysis with a focus on country-specific effects can provide more detailed policy measures and further the thresholds of aid spending.

Author Contributions: Conceptualization, N.A.A.A. and F.Q.; methodology, N.A.A.A. and Z.Z.; software, N.A.A.A.; validation, N.A.A.A., F.Q. and Z.Z.; formal analysis, N.A.A.A.; investigation, N.A.A.A., Z.Z. and F.Q.; resources N.A.A.A.; data curation, N.A.A.A.; writing-original draft preparation, N.A.A.A.; writing-review and editing, F.Q. and Z.Z. and N.A.A.A.; visualization, N.A.A.A., F.Q. and Z.Z.; supervision, F.Q.; project administration, F.Q. and N.A.A.A.; funding acquisition, Z.Z. All authors have read and agreed to the published version of the manuscript.

Funding: This research received no external funding.

Data Availability Statement: Data is available in request.

Conflicts of Interest: The authors declare no conflict of interest.

\section{Appendix A. List of Aid Categories Used to Construct the Allocated Sectoral-Aids Measure Based on Their Corresponding Potential Scope of Sectoral Growth from Creditor Reporting System}

The sectoral aid data for the first measure are in \% of GDP. It is the product of (allocated aids commitment or disbursements/GDP) by 100. Data of numerator, includes the allocated 
aids commitments or disbursements as classified in the table below, in current USD, they are obtained from OECD's Creditor Reporting System (2019) and data of denominator that is GDP in current USD, are obtained from WDI.

Table A1. List of Aid Categories Used to Construct the Allocated Sectoral-Aids Measure.

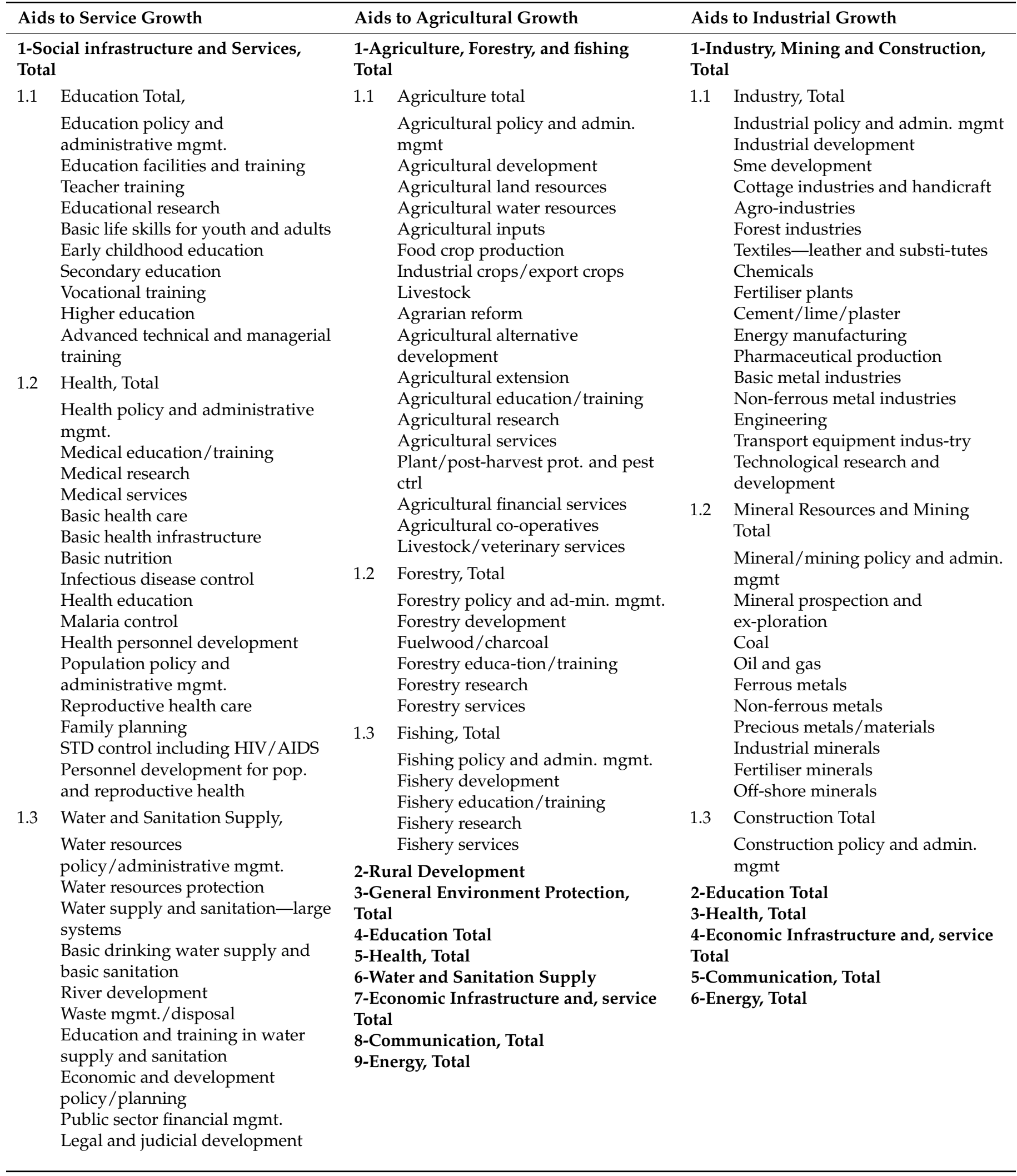


Table A1. Cont.

\begin{tabular}{l}
\hline Aids to Service Growth \\
\hline 1-Social infrastructure and Services, \\
Total \\
1.4 Government and Civil Society \\
Total, \\
Government administration \\
Strengthening civil society \\
Elections \\
Human rights \\
Free flow of information \\
Women's equality organisations \\
and institutions \\
Security system mgmt. and reform \\
Civilian peace-building, conflict \\
prevention and resolution \\
Post-conflict peace building (UN) \\
Reintegration and SALW control \\
Land mine clearance \\
Child soldiers (prevention and \\
demobilisation)
\end{tabular}

1.5 Other social infrastrucure and services Total

Social/welfare services

Employment policy and administrative mgmt.

Housing policy and administrative mgmt.

Low-cost housing

Multi-sector aid for basic social services

Culture and recreation

Statistical capacity building

Narcotics control

Social mitigation of HIV / AIDS

2-Economic Infrastructure and, service

Total

2.1 Transport

Transport policy and admin. mgmt.

Road transport

Rail transport

Water transport

Air transport

Storage

Education and training in transport and storage

2.2 Communication, Total

Communications policy and administrative mgmt.

Telecommunications

Radio/television/print media Information and communi-cation technology 
Table A1. Cont.

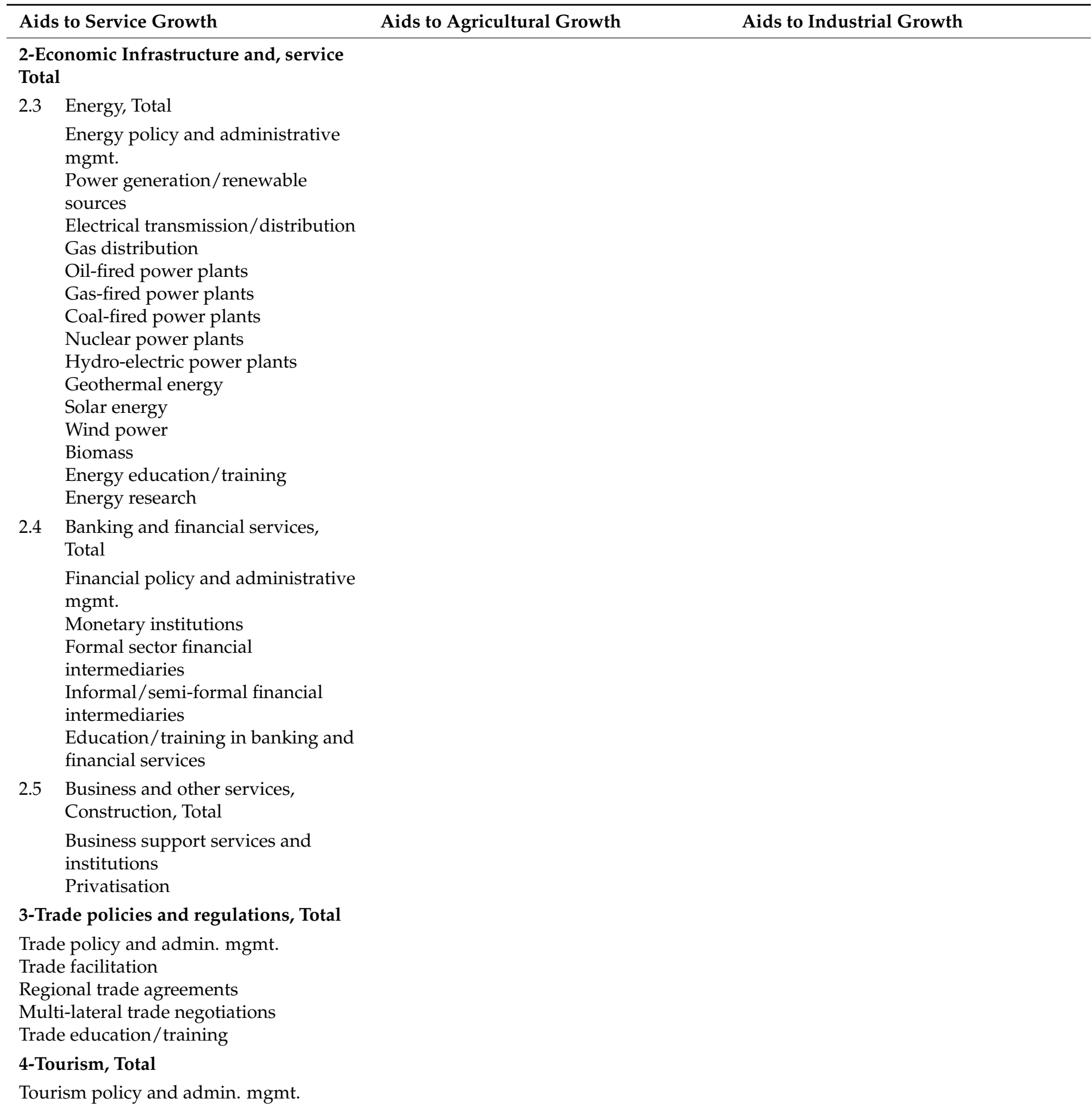

Note: These are the included categories per respective sector of growth, other sectors that may not primarily influence any of the three sectors are excluded. 


\section{Appendix B. Definition of 'Early-Impact' Aid and List of Clemens' Classification of Included Early Impact Aids Categories Measure}

Early-impact_aid is that aid which might plausibly affect growth within a few years after it is disbursed, such as aid for road construction. Aid that finances activities that might affect growth in the short term, such as budget support, is left in _early-impact_ aid._Late-impact_ aid is that which finances activities that are likely to take many years or even decades to affect growth, such as vaccination campaigns or basic education. _Humanitarian_ aid is that which finances activities without any plausible growth-related goal, such as emergency food aid and disaster relief. This classification was carried out once, before running any regressions, and never altered thereafter. The categories are mutually exclusive. Except for two small categories (administrative costs and promotion of development awareness) they are collectively exhaustive).

Table of Appendix B, shows Clemens classifications of all OECD Development Assistance Committee aid purpose codes into only early impact aids: _E_ for_early-impact_ aid, _.In our paper, we only take the early impact aids categories and excludes the long and humanitarian aids as in the original table of Clemens 2012 classification include $L_{-}$for _late-impact_aid or_H_for_humanitarian.

Table A2. List of Clemens' Classification for the Included Categories of Early-Impact Aids Measure: OECD ODA Commitment Totals by Purpose and Category, 2002-2005.

\begin{tabular}{|c|c|c|c|c|}
\hline $\begin{array}{l}\text { CRS 5-Digit Code of } \\
\text { Sector' Category }\end{array}$ & CRS Sector Purpose & USD mn & $\%$ & Category \\
\hline 21020 & Road transport & 12,532 & 3.4 & $\mathrm{E}$ \\
\hline 21030 & Rail transport & 4267 & 1.1 & $\mathrm{E}$ \\
\hline 21040 & Water transport & 1419 & 0.4 & $\mathrm{E}$ \\
\hline 21050 & Air transport & 2271 & 0.6 & $\mathrm{E}$ \\
\hline 21061 & Storage & 3 & 0.0 & $\mathrm{E}$ \\
\hline 22020 & Telecommunications & 653 & 0.2 & $\mathrm{E}$ \\
\hline 22040 & $\begin{array}{l}\text { Information and communication } \\
\text { technology }\end{array}$ & 83 & 0.0 & $\mathrm{E}$ \\
\hline 23020 & $\begin{array}{l}\text { Power generation/non-renewable } \\
\text { sources }\end{array}$ & 1944 & 0.5 & $\mathrm{E}$ \\
\hline 23030 & Power generation/renewable sources & 718 & 0.2 & $\mathrm{E}$ \\
\hline 23040 & Electrical transmission/distribution & 5712 & 1.5 & $\mathrm{E}$ \\
\hline 23050 & Gas distribution & 806 & 0.2 & $\mathrm{E}$ \\
\hline 23061 & Oil-fired power plants & 55 & 0.0 & $\mathrm{E}$ \\
\hline 23062 & Gas-fired power plants & 1959 & 0.5 & $\mathrm{E}$ \\
\hline 23063 & Coal-fired power plants & 795 & 0.2 & $\mathrm{E}$ \\
\hline 23064 & Nuclear power plants & 160 & 0.0 & $\mathrm{E}$ \\
\hline 23065 & Hydro-electric power plants & 1812 & 0.5 & $\mathrm{E}$ \\
\hline 23066 & Geothermal energy & 255 & 0.1 & $\mathrm{E}$ \\
\hline 23067 & Solar energy & 176 & 0.0 & $\mathrm{E}$ \\
\hline 23068 & Wind power & 457 & 0.1 & $\mathrm{E}$ \\
\hline 23070 & Biomass & 31 & 0.0 & $\mathrm{E}$ \\
\hline 24020 & Monetary institutions & 297 & 0.1 & $\mathrm{E}$ \\
\hline 24030 & Formal sector financial intermediaries & 1366 & 0.4 & $\mathrm{E}$ \\
\hline 24040 & $\begin{array}{l}\text { Informal/semi-formal financial } \\
\text { intermediaries }\end{array}$ & 896 & 0.2 & $\mathrm{E}$ \\
\hline 24081 & $\begin{array}{l}\text { Education/training in banking and } \\
\text { financial services }\end{array}$ & 41 & 0.0 & $\mathrm{E}$ \\
\hline 25010 & $\begin{array}{l}\text { Business support services and } \\
\text { institutions }\end{array}$ & 4133 & 1.1 & $\mathrm{E}$ \\
\hline 25020 & Privatisation & 462 & 0.1 & $\mathrm{E}$ \\
\hline
\end{tabular}


Table A2. Cont.

\begin{tabular}{|c|c|c|c|c|}
\hline $\begin{array}{l}\text { CRS 5-Digit Code of } \\
\text { Sector' Category }\end{array}$ & CRS Sector Purpose & USD mn & $\%$ & Category \\
\hline 31120 & Agricultural development & 2502 & 0.7 & $\mathrm{E}$ \\
\hline 31130 & Agricultural land resources & 681 & 0.2 & $\mathrm{E}$ \\
\hline 31140 & Agricultural water resources & 2423 & 0.7 & $\mathrm{E}$ \\
\hline 31150 & Agricultural inputs & 318 & 0.1 & $\mathrm{E}$ \\
\hline 31161 & Food crop production & 552 & 0.1 & $\mathrm{E}$ \\
\hline 31162 & Industrial crops/export crops & 115 & 0.0 & $\mathrm{E}$ \\
\hline 31163 & Livestock & 446 & 0.1 & $\mathrm{E}$ \\
\hline 31164 & Agrarian reform & 68 & 0.0 & $\mathrm{E}$ \\
\hline 31166 & Agricultural extension & 102 & 0.0 & $\mathrm{E}$ \\
\hline 31191 & Agricultural services & 270 & 0.1 & $\mathrm{E}$ \\
\hline 31192 & Plant/post-harvest prot. and pest ctrl & 141 & 0.0 & $\mathrm{E}$ \\
\hline 31193 & Agricultural financial services & 271 & 0.1 & $\mathrm{E}$ \\
\hline 31194 & Agricultural co-operatives & 128 & 0.0 & $\mathrm{E}$ \\
\hline 31195 & Livestock/veterinary services & 85 & 0.0 & $\mathrm{E}$ \\
\hline 31220 & Forestry development & 1306 & 0.4 & $\mathrm{E}$ \\
\hline 31291 & Forestry services & 8 & 0.0 & $\mathrm{E}$ \\
\hline 31320 & Fishery development & 383 & 0.1 & $\mathrm{E}$ \\
\hline 31391 & Fishery services & 197 & 0.1 & $\mathrm{E}$ \\
\hline 32120 & Industrial development & 213 & 0.1 & $\mathrm{E}$ \\
\hline 32130 & Sme development & 1903 & 0.5 & $\mathrm{E}$ \\
\hline 32140 & Cottage industries and handicraft & 41 & 0.0 & $\mathrm{E}$ \\
\hline 32161 & Agro-industries & 214 & 0.1 & $\mathrm{E}$ \\
\hline 32162 & Forest industries & 20 & 0.0 & $\mathrm{E}$ \\
\hline 32163 & Textiles-leather and substitutes & 23 & 0.0 & $\mathrm{E}$ \\
\hline 32164 & Chemicals & 15 & 0.0 & $\mathrm{E}$ \\
\hline 32165 & Fertiliser plants & 3 & 0.0 & $\mathrm{E}$ \\
\hline 32166 & Cement/lime/plaster & 32 & 0.0 & $\mathrm{E}$ \\
\hline 32167 & Energy manufacturing & 936 & 0.3 & $\mathrm{E}$ \\
\hline 32168 & Pharmaceutical production & 7 & 0.0 & $\mathrm{E}$ \\
\hline 32169 & Basic metal industries & 10 & 0.0 & $\mathrm{E}$ \\
\hline 32170 & Non-ferrous metal industries & 1 & 0.0 & $\mathrm{E}$ \\
\hline 32171 & Engineering & 107 & 0.0 & $\mathrm{E}$ \\
\hline 32172 & Transport equipment industry & 176 & 0.0 & $\mathrm{E}$ \\
\hline 32220 & Mineral prospection and exploration & 166 & 0.0 & $\mathrm{E}$ \\
\hline 32261 & Coal & 5 & 0.0 & $\mathrm{E}$ \\
\hline 32262 & Oil and gas & 1539 & 0.4 & $\mathrm{E}$ \\
\hline 32263 & Ferrous metals & 0 & 0.0 & $\mathrm{E}$ \\
\hline 32264 & Non-ferrous metals & 70 & 0.0 & $\mathrm{E}$ \\
\hline 32265 & Precious metals/materials & 1 & 0.0 & $\mathrm{E}$ \\
\hline 32266 & Industrial minerals & 3 & 0.0 & $\mathrm{E}$ \\
\hline 32267 & Fertiliser minerals & 1 & 0.0 & $\mathrm{E}$ \\
\hline 32268 & Off-shore minerals & 0 & 0.0 & $\mathrm{E}$ \\
\hline 33110 & Trade policy and admin. mgmt. & 1849 & 0.5 & $\mathrm{E}$ \\
\hline 51010 & General budget support & 21,170 & 5.7 & $\mathrm{E}$ \\
\hline 53030 & Import support (capital goods) & 360 & 0.1 & $\mathrm{E}$ \\
\hline 53040 & Import support (commodities) & 491 & 0.1 & $\mathrm{E}$ \\
\hline 60010 & Action relating to debt & 550 & 0.1 & $\mathrm{E}$ \\
\hline 60020 & Debt forgiveness & 45,812 & 12.3 & $\mathrm{E}$ \\
\hline 60030 & Relief of multi-lateral debt & 1326 & 0.4 & $\mathrm{E}$ \\
\hline 60040 & Rescheduling and refinancing & 11,057 & 3.0 & $\mathrm{E}$ \\
\hline 60061 & Debt for development swap & 130 & 0.0 & $\mathrm{E}$ \\
\hline 60062 & Other debt swap & 2 & 0.0 & $\mathrm{E}$ \\
\hline
\end{tabular}

Note. Early-impact aid is only included; as for the L, long-impact aid; $\mathrm{H}$, humanitarian aid; are not included.

The data of the second measure (Early-Impact ODA). In \% of GDP. Data for numerator are obtained from the Creditor Reporting System (CRS) 2019 and DAC 2a. All data are in current USD. Following Clemens et al. (2012), we take a prorating approach as discussed in 
Clemense2012. The numerator for early-impact aid is the product of gross ODA (Net ODA + Repayments) from DAC Table2a and the ratio of total early-impact ODA commitments as classified in Clemens et al. (2012) classification appendix over total ODA commitments from the CRS. This product is calculated by donor-recipient pair and then summed across all donors for a given recipient-year.

\section{Appendix C. Descriptive Statistics}

Table A3. Descriptive Statistics.

\begin{tabular}{ccccccc}
\hline Variable & Mean & Std. Dev. & Min & Max & Skewness & Kurtosis \\
\hline Industrial growth & 25.996 & 13.573 & 2.073 & 84.796 & 1.763 & 6.295 \\
Services growth & 44.929 & 11.380 & 10.569 & 77.020 & 0.007 & 2.828 \\
Agriculture growth & 23.437 & 15.005 & 1.954 & 79.042 & 0.671 & 3.342 \\
Aids to services growth & 8.150 & 8.594 & 0.047 & 71.000 & 2.556 & 13.001 \\
Aids to agriculture growth & 0.359 & 0.498 & -0.579 & 5.770 & 3.279 & 24.028 \\
Aids to industry growth & 0.067 & 0.287 & 0.000 & 5.260 & 11.018 & 159.304 \\
Employment & 3.213 & 3.136 & 0.066 & 18.138 & 1.965 & 7.757 \\
Trade Openness & 72.155 & 33.216 & 0.027 & 311.354 & 1.743 & 10.936 \\
Domestic Saving & 10.739 & 21.282 & -141.974 & 74.621 & -1.774 & 14.640 \\
Government Spending & 14.408 & 6.149 & -2.742 & 55.275 & 0.829 & 6.723 \\
Government Effectiveness & 10.739 & 19.930 & 0.510 & 83.060 & 0.572 & 2.206 \\
Political Stability & 27.290 & 20.289 & 0.000 & 93.750 & 0.584 & 2.400 \\
Private Capital & 26.462 & 33.052 & -82.892 & 516.764 & 11.010 & 143.206 \\
Control of corruption & 7.476 & $2,847,207.000$ & 0.000 & $19,900,000$ & 6.204 & 143.206 \\
The use of energy & $450,155.100$ & 524.931 & 63.005 & 2986.056 & 2.335 & 9.360 \\
Arable land & 633.134 & $3,004,498.000$ & 0.378 & $19,900,000.000$ & 5.891 & 35.927 \\
Access to electricity & $498,846.400$ & 32.617 & 0.010 & 100.414 & 0.700 & 2.155 \\
\hline
\end{tabular}

\section{Appendix D. Descriptive Statistics 2 (Alternative Traditional Control Variables)}

Table A4. Descriptive Statistics 2 (Alternative Traditional Control Variables).

\begin{tabular}{|c|c|c|c|c|c|c|}
\hline Variables & Mean & Std. Dev. & Min & Max & Skew. & Kurt. \\
\hline Oda gross loans & 72.812 & 141.089 & -0.16 & 989.92 & 3.315 & 16.18 \\
\hline Repayments & 3.110 & 9.730 & -2.771 & 2.080 & 15.127 & 305.222 \\
\hline Early impact aids & 1.614 & 6.885 & -0.038 & 116.069 & 9.913 & 136.072 \\
\hline Initial life expectancy & 54.821 & 8.9 & 43.183 & 72.522 & 0.624 & 2.268 \\
\hline Corruption & 2.044 & 0.845 & 0 & 5 & 0.286 & 3.28 \\
\hline Law and Order & 2.973 & 1.12 & 0.5 & 6 & 0.552 & 2.992 \\
\hline Bureaucracy Quality & 1.351 & 0.792 & 0 & 3.5 & -0.414 & 2.218 \\
\hline $\begin{array}{c}\text { Democrat ic } \\
\text { Accountability }\end{array}$ & 3.213 & 1.233 & 0 & 5.5 & -0.081 & 2.169 \\
\hline Institutional Quality & 7.17 & 2.209 & 2.25 & 15.25 & 0.168 & 2.755 \\
\hline Tropics & 0.666 & 0.447 & 0 & 1 & -0.721 & 1.6 \\
\hline $\begin{array}{l}\text { Initial GDP } \\
\text { Per capita }\end{array}$ & 4.262 & 4.98 & -3.757 & 23.053 & 1.7 & 7.407 \\
\hline GDP per capita & 1.732 & 5.134 & -34.96 & 50.236 & 0.085 & 25.523 \\
\hline Oda commitments & 689.318 & 1297.877 & 4.858 & 20274.47 & 8.621 & 104.21 \\
\hline Population Growth & 2.596 & 0.915 & -0.055 & 7.902 & 0.815 & 7.486 \\
\hline Initial Income per capita & 685.817 & 830.066 & 42.8783 & 3287.965 & 1.775 & 5.394 \\
\hline Broad money & 40.346 & 43.523 & 2.857408 & 258.831 & 2.744 & 11.743 \\
\hline
\end{tabular}




\section{Appendix E. Proxies Definitions and Data Sources of Control Variables (Initial Specification)}

Table A5. Proxies Definitions and Data Sources of Control Variables (Initial Specification).

\begin{tabular}{|c|c|c|}
\hline Variables & Indicator/Proxy & Specification \\
\hline Industrial Growth & Industrial Value added & $\begin{array}{l}\text { Industry corresponds to ISIC divisions } \\
10-45 \text { and includes manufacturing (ISIC } \\
\text { divisions 15-37). It comprises value } \\
\text { added in mining, manufacturing (also } \\
\text { reported as a separate subgroup), } \\
\text { construction, electricity, water, and gas. } \\
\text { Value added is the net output of a sector } \\
\text { after adding up all outputs and } \\
\text { subtracting intermediate inputs. }\end{array}$ \\
\hline
\end{tabular}

Agriculture corresponds to ISIC divisions 1-5 and includes forestry, hunting, and fishing, as well as cultivation of crops Agricultural Growth Agricultural Value added and livestock production. Value added is the net output of a sector after adding up all outputs and subtracting intermediate

inputs.
Services correspond to ISIC divisions 50-99 and they include value added in wholesale and retail trade (including hotels and restaurants), transport, and government, financial, professional, and personal services such as education, health care, and real estate services. Also included are imputed bank service charges, import duties, and any statistical discrepancies noted by national compilers as well as discrepancies arising from rescaling. Value added is the net output of a sector after adding up all outputs and subtracting intermediate inputs. It is calculated without making deductions for depreciation of fabricated assets or depletion and degradation of natural resources. The industrial origin of value added is determined by the International Standard Industrial Classification (ISIC), revision 3 or 4 .
WDI \& OECD)

Indexmundi, SESRIC

WDI \& OECD (national accounts data)

Indexmundi, SESRIC
Services Growth

Services Value added
Allocated aids for social infrastructure \& services total+, economic

Aids for services growth infrastructure and services total+ trade policy and regulation, total +tourism, total

Allocated aids for

Aids for agricultural growth
Agriculture, Forestry,

Fishing total+ Rural

Development total
Categories of aids that primarily effect services growth

CRS, OECD Indexmundi, SESRIC

WDI \& OECD (national 
Table A5. Cont.

\begin{tabular}{|c|c|c|c|}
\hline Variables & Indicator/Proxy & Specification & Data Source \\
\hline Aids for industry & $\begin{array}{l}\text { Allocated aids industry, } \\
\text { mining and construction } \\
\text { total }\end{array}$ & $\begin{array}{l}\text { Categories of aids that primarily effect } \\
\text { agricultural growth }\end{array}$ & CRS, OECD \\
\hline Early impact aids (2) & $\begin{array}{l}\text { The numerator for } \\
\text { early-impact aid is the } \\
\text { product of gross ODA } \\
\text { (Net ODA + Repayments) } \\
\text { and the ratio of total } \\
\text { early-impact ODA } \\
\text { commitments as classified } \\
\text { in Clemens et al. (2012) } \\
\text { classification and the } \\
\text { current study Appendix B } \\
\text { over total ODA } \\
\text { commitments. }\end{array}$ & $\begin{array}{l}\text { Allocated categories of aids that might } \\
\text { plausibly affect growth within a few } \\
\text { years after it is disbursed, such as aid for } \\
\text { road construction. Aid that finances } \\
\text { activities that might affect growth in the } \\
\text { short term, such as budget support, is left } \\
\text { in_early-impact_aid }\end{array}$ & $\begin{array}{l}\text { WDI, } \\
\text { (CRS) } 2019 \text { and DAC 2a }\end{array}$ \\
\hline
\end{tabular}

We used the most inclusive measure of net private capital flows, which is computed as Net Private Equity/GDP + Private Debt Flows/GDP. The net private equity is computed as Net FDI + Portf Equity Capital Flows

Private Capita (the most inclusive
(\% GDP), and private debt

flows/GDP is computed as Net Total Debt from Private Creditors/GDP, which represents the annual changes in the stock of total external debt from private creditors, including private nonguaranteed debt flows, PPG debt flows and private creditors.

\begin{tabular}{|c|c|c|c|}
\hline Trade openness & $\begin{array}{l}\text { Total exports plus } \\
\text { imports/GDP }\end{array}$ & Total exports plus imports/GDP & WDI \\
\hline Employment & Employers & Employers, total (\% of total employment) & WDI \\
\hline $\begin{array}{l}\text { Gross domestic savings } \\
(\% \text { of GDP) }\end{array}$ & & $\begin{array}{l}\text { Gross domestic savings are calculated as } \\
\text { GDP less final consumption expenditure } \\
\text { (total consumption) }\end{array}$ & WDI \\
\hline $\begin{array}{l}\text { Official development } \\
\text { assistance }\end{array}$ & ODA & $\begin{array}{l}\text { Net official development assistance } \\
\text { (ODA) consists of disbursements of loans } \\
\text { made on concessional terms (net of } \\
\text { repayments of principal) and grants by } \\
\text { official agencies of the members of the } \\
\text { (DAC), }\end{array}$ & OECD \\
\hline
\end{tabular}

Net Private Equity and Private Debt Flows/GDP. The most inclusive measure of net private capital flows.
Equity flows come from IMF and Private debt from WB-GDF database (DAC), 
Table A5. Cont.

\begin{tabular}{|c|c|c|c|}
\hline Variables & Indicator/Proxy & Specification & Data Source \\
\hline Government Spending & $\begin{array}{l}\text { General government final } \\
\text { consumption expenditure } \\
(\% \text { of GDP) }\end{array}$ & $\begin{array}{l}\text { General government final consumption } \\
\text { expenditure (formerly general } \\
\text { government consumption) includes all } \\
\text { government current expenditures for } \\
\text { purchases of goods and services } \\
\text { (including compensation of employees). } \\
\text { It also includes most expenditures on } \\
\text { national defense and security but } \\
\text { excludes government military } \\
\text { expenditures that are part of government } \\
\text { capital formation. }\end{array}$ & WDI \& OECD \\
\hline Political stability & Political stability & $\begin{array}{l}\text { Political Stability and Absence of } \\
\text { Violence/Terrorism captures perceptions } \\
\text { of the likelihood that the government will } \\
\text { be destabilized or overthrown by } \\
\text { unconstitutional }\end{array}$ & $\begin{array}{l}\text { Worldwide Governance } \\
\text { Indicators, The World } \\
\text { Bank }\end{array}$ \\
\hline
\end{tabular}

Government Effectiveness captures perceptions of the quality of public services, the quality of the civil service and the degree of its independence from political pressures, the quality of policy formulation and implementation, and the credibility of the government's commitment to such policies
Worldwide Governance Indicators, The World Bank

Land under temporary crops

(double-cropped areas are counted once), temporary meadows for mowing or for pasture, land under market or kitchen gardens, and land temporarily fallow. Land abandoned as a result of shifting cultivation is excluded.

Arable land (\% of land area)
It refers to the percentage of people in a given area that have relatively simple, stable access to electricity. ... Not all countries and areas have equal access to electricity, and the level of access can be indicative of the development level of the country or area in question
Access to electricity (\% of population)
Energy use refers to use of primary energy before transformation to other end-use fuels, which is equal to indigenous production plus imports and WDI stock changes, minus exports and fuels supplied to ships and aircraft engaged in international transport

It measures the perception of how much public power is exercised for private gain, including both petty and grand forms of corruption, and how much the state is captured by elites and private interests
Control of Corruption Control of Corruption 


\section{Appendix F. Variables Proxies Definitions and Data Sources of Alternative Control Traditional Variables}

Table A6. Variables Proxies Definitions and Data Sources of Alternative Control Traditional Variables.

\begin{tabular}{|c|c|c|c|}
\hline Variables & Indicator/Proxy & Specification & Data Source \\
\hline Tropics & $\begin{array}{l}\text { Geographical tropics, \% } \\
\text { land area in geographical } \\
\text { tropics, calculated in } \\
\text { equal-area projection, } \\
\text { (Dalgaard et al. 2004; } \\
\text { Gallup et al. 1999) }\end{array}$ & $\begin{array}{l}\text { Indicative of location in tropics as in } \\
\text { Gallup et al. (1999) }\end{array}$ & Country Geography Data \\
\hline Repayments. & \multicolumn{2}{|c|}{$\begin{array}{l}\text { 'ODA (OA) Loans Received/GDP, the numerator is 'ODA (OA) Loans } \\
\text { Received [in current USD/The denominator as in (Burnside and Dollar } \\
\text { 2000; Rajan and Subramanian 2008a) }\end{array}$} & $\begin{array}{c}\text { WDI, } \\
\text { (CRS) } 2019 \text { and DAC 2a }\end{array}$ \\
\hline M2/GDP. & $\begin{array}{l}\text { Money and quasi-money } \\
\text { (M2) as \% of GDP GDP, } \\
\text { (Rajan and Subramanian } \\
\text { 2008a; Selaya and Thiele } \\
\text { 2010;Burnside and Dollar } \\
2000\end{array}$ & $\begin{array}{l}\text { Money and quasi money (M2) comprise } \\
\text { the sum of currency outside banks, } \\
\text { demand deposits other than those of the } \\
\text { central government, and the time, } \\
\text { savings, and foreign currency deposits of } \\
\text { resident sectors other than the central } \\
\text { government. }\end{array}$ & WDI \\
\hline Population Growth & $\begin{array}{l}\text { Log population growth } \\
\text { (annual population } \\
\text { growth rate), (Boone 1996; } \\
\text { Dalgaard et al. 2004; } \\
\text { Burnside and Dollar 2000) }\end{array}$ & $\begin{array}{l}\text { The population is based on the de facto } \\
\text { definition of population, which counts all } \\
\text { residents regardless of legal status or } \\
\text { citizenship }\end{array}$ & WDI \\
\hline Initial life expectancy & $\begin{array}{l}\text { Initial life expectancy } \\
\text { (Clemens et al. 2004, 2012; } \\
\text { Rajan and Subramanian } \\
\text { 2008a) }\end{array}$ & $\begin{array}{l}\text { Life expectancy is based on an estimate of } \\
\text { the average age that members of a } \\
\text { particular population group will be when } \\
\text { they die }\end{array}$ & WDI \\
\hline Institutional quality & $\begin{array}{l}\text { It is a composite of four ind } \\
4 \text { components (bureaucratic } \\
\text { accountability), as in Cleme } \\
\text { (2008a) }\end{array}$ & $\begin{array}{l}\text { ctors we use period averages of the sum of } \\
\text { quality, law\& order, corruption democracy } \\
\text { s et al. (2004) and Rajan and Subramanian }\end{array}$ & $\begin{array}{l}\text { ICRG } \\
\text { PRS Group's }\end{array}$ \\
\hline
\end{tabular}

The numerator for early-impact aid is the product of gross ODA

(Net ODA + Repayments) and the ratio of total early-impact ODA

Early impact aids commitments as classified in Clemens et al. (2012) classification and the current study Appendix B over total ODA commitments.

The initial period share of the first non-missing value in each period of

Initial Per capita Income

per-capita income as in
(Clemens et al. 2004, 2012;

Rajan and Subramanian 2008a)
Allocated categories of aids that might plausibly affect growth within a few years after it is disbursed, such as aid for road construction. Aid that finances activities that might affect growth in the short term, such as budget support, is left in_early-impact_aid
WDI,

(CRS) 2019 and DAC 2a

It measures the average income earned per person in a given area (city, region, country, etc.) in a specified year. It is calculated by dividing the area's total WDI income by its total population. 


\section{Appendix G. Unit Root Tests}

Table A7. Unit Root Tests.

\begin{tabular}{ccc}
\hline Variables & IPS Test & ADF Fisher Type \\
\hline Sectoral aids industry & $-15.6972^{* * *} \mathrm{I}(0)$ & $-23.5148^{* * *} \mathrm{I}(0)$ \\
Sectoral aids Agriculture & $-14.2899^{* * *} \mathrm{I}(0)$ & $-24.9957^{* * *} \mathrm{I}(0)$ \\
Sectoral aids Services & $-16.5402^{* * *} \mathrm{I}(0)$ & $-24.4563^{* * *} \mathrm{I}(0)$ \\
Odagdp100 & $-16.7531^{* * *} \mathrm{I}(0)$ & $-24.8659^{* * *} \mathrm{I}(0)$ \\
Domestic Saving & $-16.9610^{* * *} \mathrm{I}(0)$ & $-25.3291^{* * *} \mathrm{I}(0)$ \\
Government Spending & $-14.9676^{* *} \mathrm{I}(0)$ & $-21.5321^{* * *} \mathrm{I}(0)$ \\
Government Effectiveness & $-16.2424^{* *} \mathrm{I}(0)$ & $-23.6048^{* * *} \mathrm{I}(0)$ \\
Political stability & $-16.6666^{* * *} \mathrm{I}(0)$ & $-24.7280^{* * *} \mathrm{I}(\mathrm{I})$ \\
Trade openness & $-14.4043^{* * *} \mathrm{I}(0)$ & $-19.8126^{* *} \mathrm{I}(0)$ \\
Private Capital & $-16.6546^{* * *} \mathrm{I}(0)$ & $-24.7364^{* * *} \mathrm{I}(\mathrm{I})$ \\
Industrial Value added & $-15.5572^{* * *} \mathrm{I}(0)$ & $-22.2410^{* * *} \mathrm{I}(0)$ \\
Agriculture Value added & $-12.2173^{* * *} \mathrm{I}(0)$ & $-15.8287^{* * *} \mathrm{I}(0)$ \\
Services Value added & $-14.1299^{* * *} \mathrm{I}(0)$ & $-19.8021^{* * *} \mathrm{I}(0)$ \\
Employment & $-15.3577^{* * *} \mathrm{I}(0)$ & $-21.8893^{* * *} \mathrm{I}(0)$ \\
GDP & $-16.7491^{* * *} \mathrm{I}(0)$ & $-24.7226^{* * *} \mathrm{I}(0)$ \\
Control of corruption & $-16.5962^{* * *} \mathrm{I}(0)$ & $-24.3957^{* * *} \mathrm{I}(0)$ \\
The use of energy & $--10.7176^{* * *} \mathrm{I}(0)$ & $-22.0644^{* * *} \mathrm{I}(0)$ \\
Arable Land & $-16.4138^{* * *} \mathrm{I}(0)$ & $-23.9380^{* * *} \mathrm{I}(0)$ \\
Access to electricity & $-6.8424^{* * *} \mathrm{I}(0)$ & $-7.8350^{* * *} \mathrm{I}(0)$ \\
\hline
\end{tabular}

Superscripts ***, ${ }^{* *}$ denote statistical significance at the $1 \%$ and $5 \%$ and $10 \%$ levels, respectively. $t$ statistics and $z$ statistics values are presented for unit root tests at level and first difference. $\mathrm{I}(0)$ shows stationary at level while, $\mathrm{I}(\mathrm{I})$ presents the stationarity at first difference.

\section{Appendix H. Unit Root Tests (Standard-Literature Control Variables)}

Table A8. Unit Root Tests (Standard-Literature Control Variables).

\begin{tabular}{ccc}
\hline Variables & IPS Test & ADF Fisher Type \\
\hline Early impacts aids & $-13.0948^{* * *} \mathrm{I}(0)$ & $-9.4739^{* * *} \mathrm{I}(0)$ \\
tropics & $-4.4270^{* * *} \mathrm{I}(0)$ & $-4.8319^{* * *} \mathrm{I}(0)$ \\
Repayments & $-13.5874^{* * *} \mathrm{I}(0)$ & $-17.8352^{* * *} \mathrm{I}(0)$ \\
Initial per capita income & $-12.6331^{* * *} \mathrm{I}(0)$ & $-20.1427^{* * *} \mathrm{I}(0)$ \\
Initial GDP per capita & $-13.6932^{* * *} \mathrm{I}(0)$ & $-25.3291^{* * *} \mathrm{I}(0)$ \\
Initial life expectancy & $-6.5930^{* * *} \mathrm{I}(0)$ & $-18.1625^{* * *} \mathrm{I}(0)$ \\
Intuitional quality & $-12.6401^{* * *} \mathrm{I}(0)$ & $-9.4739^{* * *} \mathrm{I}(0)$ \\
Broad money & $-7.8095^{* * *} \mathrm{I}(0)$ & $-19.5540^{* * *} \mathrm{I}(\mathrm{I})$ \\
Population Growth & $-13.3353^{* * *} \mathrm{I}(0)$ & $-24.7364^{* * *} \mathrm{I}(\mathrm{I})$ \\
Oda Gross loan & $-12.1773^{* * *} \mathrm{I}(0)$ &
\end{tabular}

Superscripts $* * *$ denote statistical significance at the $1 \%$ and $5 \%$ and $10 \%$ levels, respectively. $t$ statistics and $z$ statistics values are presented for unit root tests at level and first difference. I(0) shows stationary at level while, $\mathrm{I}(\mathrm{I})$ presents the stationarity at first difference.

\section{Appendix I. Instrumented Aids with Three Lagged Periods and GMM and Pooled OLS Driscoll-Kraay Standard Errors}

Table A9. Instrumented Aids with Three Lagged Periods and GMM and Pooled OLS Driscoll-Kraay Standard Errors.

\begin{tabular}{cccc}
\hline & \multicolumn{3}{c}{ Lagged Aids $(\mathbf{t}-\mathbf{1 , t}-\mathbf{2 , t}-\mathbf{3})$} \\
\hline Dependent Variables & Industrial Growth & Agriculture Growth & Service Growth \\
\hline \multirow{2}{*}{ Sectoral aids $(\mathrm{t}-1)$} & -0.026 & $3.293^{* * *}$ & $-0.148^{* * *}$ \\
& $-(0.052)$ & 0.586 & $-(0.053)$ \\
\hline
\end{tabular}


Table A10. Cont.

\begin{tabular}{|c|c|c|c|c|c|c|}
\hline \multirow[b]{2}{*}{$\begin{array}{c}\text { Dependent } \\
\text { Variables }\end{array}$} & \multicolumn{3}{|c|}{ Aids Commitments } & \multicolumn{3}{|c|}{ Aids Disbursements } \\
\hline & $\begin{array}{l}\text { Industrial } \\
\text { Sector Growth } \\
\text { Equation }\end{array}$ & $\begin{array}{l}\text { Agriculture } \\
\text { Sector Growth } \\
\text { Equation }\end{array}$ & $\begin{array}{l}\text { Service Sector } \\
\text { Growth } \\
\text { Equation }\end{array}$ & $\begin{array}{l}\text { Industrial } \\
\text { Sector Growth } \\
\text { Equation }\end{array}$ & $\begin{array}{l}\text { Agriculture } \\
\text { Sector Growth } \\
\text { Equation }\end{array}$ & $\begin{array}{c}\text { Service Sector } \\
\text { Growth } \\
\text { Equation }\end{array}$ \\
\hline & GMM & GMM & GMM & GMM & GMM & GMM \\
\hline Political & $0.043^{* * *}$ & $-0.085^{* * *}$ & $-0.021^{* *}$ & $0.065 *$ & $-0.118^{* * *}$ & -0.043 \\
\hline Stability & -4.1 & $(-3.71)$ & $(-2.69)$ & -2.31 & $(-4.05)$ & $(-1.71)$ \\
\hline Private Capital & $\begin{array}{c}0.113^{* * *} \\
-7.78\end{array}$ & $\begin{array}{l}-0.013 \\
(-1.20)\end{array}$ & $\begin{array}{c}-0.178^{* * *} \\
(-11.39)\end{array}$ & $\begin{array}{l}0.105^{*} \\
-2.57\end{array}$ & $\begin{array}{l}-0.009 \\
(-0.82)\end{array}$ & $\begin{array}{c}0.01 \\
-0.97\end{array}$ \\
\hline & $2.875^{* * * *}$ & $49.484^{* * *}$ & $39.206^{* * * *}$ & 1.003 & $48.271^{* * * *}$ & $39.101 * * *$ \\
\hline constant & -5.66 & -39.96 & -100.49 & -0.66 & -30.23 & -27.72 \\
\hline $\begin{array}{l}\text { Observations \& } \\
\text { countries }\end{array}$ & \multicolumn{3}{|c|}{37 countries ( 813 Obs.) } & \multicolumn{3}{|c|}{30 countries (660 Obs.) } \\
\hline $\mathrm{AR}(1 \& 2)$ & $-2.86^{* * *}$ & $-9.79 * *$ & $-2.10^{* *}$ & $-4.25^{* * *}$ & $-9.56^{* * *}$ & $-8.23^{* * *}$ \\
\hline AK $(1 \propto 2)$ & $-1.97^{* *}$ & $0.50 *(0.105)$ & $-1.64 *$ & $1.80 *$ & -0.23 & 0.33 \\
\hline Sargan OIR & $3858.88^{* * *}$ & $720.23 *$ & $6762.42^{* * *}$ & $218.88^{* * *}$ & 522.11 & $589.84^{* *}$ \\
\hline $\begin{array}{l}\text { Wald chi2//R- } \\
\text { squared }\end{array}$ & $8887.02^{* * *}$ & $7189.06^{* * *}$ & $4915.07^{* * *}$ & $626.03^{* * *}$ & $960.42^{* * *}$ & $368.51^{* * *}$ \\
\hline
\end{tabular}

\section{Appendix K. Lists of the Literature Concerning Allocated Aids to Specific Sectors}

Table A11. Lists of the Literature Concerning Allocated Aids to Specific Sectors.

\begin{tabular}{|c|c|c|c|c|}
\hline Study and Title & $\begin{array}{l}\text { Method\& } \\
\text { Estimation }\end{array}$ & $\begin{array}{l}\text { Foreign Aids } \\
\text { Variable }\end{array}$ & Objectives and Argument & Expected Results \\
\hline Ssozi et al. (2019) & GMM & $\begin{array}{l}\text { Allocated aids for } \\
\text { agriculture }\end{array}$ & $\begin{array}{l}\text { To find out whether official } \\
\text { development assistance for } \\
\text { agriculture is effective. }\end{array}$ & $\begin{array}{l}\text { There is a positive } \\
\text { relationship between } \\
\text { development assistance and } \\
\text { agricultural productivity in } \\
\text { general. However, when } \\
\text { broken down into the major } \\
\text { agricultural recipient sectors, } \\
\text { there is a substitution effect } \\
\text { between food crop } \\
\text { production and industrial } \\
\text { crop production. }\end{array}$ \\
\hline $\begin{array}{l}\text { Reuben Adeolu } \\
\text { Alabi (2014) }\end{array}$ & $\begin{array}{l}\text { Dynamic } \\
\text { specification \& } \\
\text { (GMM) }\end{array}$ & $\begin{array}{l}\text { Allocated aids for } \\
\text { agriculture }\end{array}$ & $\begin{array}{l}\text { To investigate the impact of } \\
\text { foreign agricultural aid on } \\
\text { agricultural GDP and } \\
\text { productivity in Sub-Saharan } \\
\text { Africa (SSA). }\end{array}$ & $\begin{array}{l}\text { He found positive results of } \\
\text { aids allocated to agriculture } \\
\text { growth } \\
\text { The econometric analysis } \\
\text { suggests that foreign } \\
\text { agricultural aid has a } \\
\text { positive and significant } \\
\text { impact on agricultural GDP } \\
\text { and agricultural productivity } \\
\text { at } 10 \% \text { significance, and that } \\
\text { disaster and conflict also } \\
\text { have a positive and } \\
\text { significant impact on aid } \\
\text { receipt at } 5 \% \text { significance. }\end{array}$ \\
\hline
\end{tabular}


Table A11. Cont.

\begin{tabular}{|c|c|c|c|c|}
\hline Study and Title & $\begin{array}{l}\text { Method\& } \\
\text { Estimation }\end{array}$ & $\begin{array}{l}\text { Foreign Aids } \\
\text { Variable }\end{array}$ & Objectives and Argument & Expected Results \\
\hline $\begin{array}{l}\text { Shanka Prasad } \\
\text { Ghimire et al. } \\
\text { (2013) }\end{array}$ & SUR & $\begin{array}{l}\text { Allocated Aids for } \\
\text { the corresponding } \\
\text { sector }\end{array}$ & $\begin{array}{l}\text { To examines the relationship } \\
\text { between the allocated aids to } \\
\text { three specific sectors of } \\
\text { export promotion } \\
\text { (agriculture, services and } \\
\text { industry) }\end{array}$ & $\begin{array}{l}\text { All the corresponding } \\
\text { allocated for each sector } \\
\text { showed positive and highly } \\
\text { significant impact. }\end{array}$ \\
\hline Hugie (2011) & SUR & $\begin{array}{l}\text { Allocated aids to } \\
\text { the targeted sector }\end{array}$ & $\begin{array}{l}\text { This study addresses } \\
\text { whether the absolute and } \\
\text { relative impact of economic, } \\
\text { political, and humanitarian } \\
\text { variables that restrain or } \\
\text { boost U.S. foreign assistance } \\
\text { varies for different types of } \\
\text { aid, } \\
\text { from a strictly domestic } \\
\text { decision-making framework }\end{array}$ & $\begin{array}{l}\text { He found that various aid } \\
\text { budgets unlikely respond } \\
\text { with respect to the } \\
\text { explanatory variables. }\end{array}$ \\
\hline
\end{tabular}
decision-making framework

To evaluate the impact of foreign aid to five services sectors (transportation, information and communications

Ferro et al. (2014) Identification $\quad \begin{aligned} & \text { Aids allocated to } \\ & \text { the targeted five }\end{aligned}$ strategy

technologies (ICT), energy, banking/financial services, and business services) on exports of downstream manufacturing sectors in developing countries.

\section{To examined sectoral} analysis of the impact of

Multivariate

Goshu (2014)

\section{Vector Auto}

Regression analysis
Allocated aid to the targeted sector

foreign aid on aggregate and sectoral economic growth in Ethiopia over the period 1981 to 2012

Panel data estimation techniques controlling for country-specific effects and potential endogeneity of regressors.

Ndikumana and Pickbourn (2017)

Pickbourn and

Ndikumana (2016)
GMM, Fixed effect, IRLS, OLS
Allocated aids for gender inequality
To investigate whether targeting foreign aid to the water and sanitation sector can help achieve the goal of expanding access to water and sanitation services in sub-Saharan Africa.

to examine the impact of bilateral official aid disbursements aid and its sectoral allocation on overall gender inequality as well as on gender inequality in health and education
They find a positive effect of aid to services, in general, on downstream manufacturing exports of developing countries across regions and income-level groups

His results implied that allocated for certain sectors is ineffective in achieving its objectives of economic growth

The econometric results suggest that increased aid targeted to the supply of water and sanitation is associated with increased access to these services, although the relationship is non-linear.

We find that the impact of aid on gender inequality is dependent on initial human development and per capita income 
Table A11. Cont.

\begin{tabular}{|c|c|c|c|c|}
\hline Study and Title & $\begin{array}{l}\text { Method\& } \\
\text { Estimation }\end{array}$ & $\begin{array}{l}\text { Foreign Aids } \\
\text { Variable }\end{array}$ & Objectives and Argument & Expected Results \\
\hline $\begin{array}{l}\text { Claudia R. } \\
\text { Williamson (2008) }\end{array}$ & $\begin{array}{l}\text { Fixed effect, } \\
\text { instrumental } \\
\text { variables }\end{array}$ & $\begin{array}{l}\text { Aids allocated to } \\
\text { promoting human } \\
\text { development }\end{array}$ & $\begin{array}{l}\text { to investigate the } \\
\text { effectiveness of aid in } \\
\text { promoting human } \\
\text { development. }\end{array}$ & $\begin{array}{l}\text { indicate that foreign aid is } \\
\text { ineffective at increasing } \\
\text { overall health and is an } \\
\text { unsuccessful human } \\
\text { development tool }\end{array}$ \\
\hline $\begin{array}{l}\text { Findley and } \\
\text { Hawkins (2010). }\end{array}$ & Statistical matching & $\begin{array}{l}\text { Allocated } \\
\text { PLAID/AidData } \\
\text { foreign aid data }\end{array}$ & $\begin{array}{l}\text { To examine the } \\
\text { sector-by-sector (education, } \\
\text { democracy, the respect of } \\
\text { human rights, the } \\
\text { environment, and terrorism } \\
\text { prevention) effectiveness of } \\
\text { foreign }\end{array}$ & $\begin{array}{l}\text { The results offer initial } \\
\text { support for the need to } \\
\text { disaggregate aid and the } \\
\text { development outcomes that } \\
\text { aid is often designed to } \\
\text { address }\end{array}$ \\
\hline
\end{tabular}

\section{Appendix L. The Sample of the Study}

Table A12. 37 Selected Countries from SSA and MENA Regions.

\begin{tabular}{|c|c|c|c|}
\hline No & Sub-Sahara African & No & MENA Countries \\
\hline 1 & Angola & 1 & Egypt \\
\hline 2 & Benin & 2 & Iraq \\
\hline 3 & Burundi & 3 & Jordan \\
\hline 4 & C. African Republic & 4 & Lebanon \\
\hline 5 & Chad & 5 & Morocco \\
\hline 6 & Congo, Dem. Rep. & 6 & Tunisia \\
\hline 7 & Congo, Rep. & 7 & West Bank and Gaza Strip \\
\hline 8 & Côte d'Ivoire & 8 & Yemen \\
\hline 9 & D.R Congo & & \\
\hline 10 & Gambia & & \\
\hline 11 & Guinea & & \\
\hline 12 & Guinea-Bissau & & \\
\hline 13 & Kenya & & \\
\hline 14 & Liberia & & \\
\hline 15 & Liberia & & \\
\hline 16 & Madagascar & & \\
\hline 17 & Malawi & & \\
\hline 18 & Mali & & \\
\hline 19 & Mauritania & & \\
\hline 20 & Mozambique & & \\
\hline 21 & Namibia & & \\
\hline 22 & Niger & & \\
\hline
\end{tabular}


Table A12. Cont.

\begin{tabular}{|c|c|c|c|}
\hline No & Sub-Sahara African & No & MENA Countries \\
\hline 23 & Nigeria & & \\
\hline 24 & Rwanda & & \\
\hline 25 & South Africa & & \\
\hline 26 & Togo & & \\
\hline 27 & Uganda & & \\
\hline 28 & Zambia & & \\
\hline 29 & Zimbabwe & & \\
\hline
\end{tabular}

\section{Notes}

1 Currently, the debate of the aid-growth nexus is specifically directed to Sub-Saharan Africa (henceforth, SSA) due to several factors. Most importantly, in spite of substantial aid flows to SSA, the crucial purpose of the United Nation's Millennium Development Goals, to reduce poverty to half of the 1990 level by 2015, is probably not going to be met in SSA (Addison et al. 2005). Moreover, the existence of increasing signs of donor fatigue due to the global financial crisis and growing concern for government debt levels (OECD 2011) in turn threatens to further stagnate economic development in the regions.

The Literature Review section provides a detailed discussion about the remaining gaps in this area of the aid literature.

More details about these issues are found in the Literature Review.

There were increasing numbers of inefficient but large infrastructure investment projects in SSA as a result of less grounded investment decisions that were motivated by political considerations. The inefficient outcomes of these projects stem from non-adaptation to the real needs of the economy and poor maintenance capabilities (Keza 2005).

5 Sectoral aid comprises specified categories of aid that are likely to affect the growth of the corresponding sectors. We collected the sectoral aid data from official development assistance bilateral aid flows as the ODA is segregated and classified for different economic and non-economic sectors according to the CRS of the OECD.

6 More information about constructing these two measures can be found in the Methodology section.

7 The characteristics and assumptions that are reminiscent of displacement theory, fiscal response and fungibility, Dutch disease etc.

8 Standard literature of the aid-growth nexus means the most prominent papers or the most influential cited studies in the aid-growth literature, including: (Boone 1996; Clemens et al. 2004, 2012; Boone 1996; Burnside and Dollar 2000; Collier and Dollar 2002; Dalgaard et al. 2004; Rajan and Subramanian 2008a).

9 This is the most inclusive measure of net private capital flows as clarified in Alfaro et al. (2014), where the net private equity is computed as Net FDI + Portf Eqty Capital Flows (\% GDP), and private debt flows/GDP is the Net Total Debt from Private Creditors/GDP, which is the annual change in the stock of the total external debt from private creditors, including private nonguaranteed debt flows and PPG debt flows.

This means that the excess aid inflow may be used to invest in low-productivity sectors and/or to increase government consumption spending and/or to fund tax reduction. The former two would make aid less effective while the latter would deter domestic savings and investments via upward pressure on prices and interest rates.

11 Aid inflows bring in a source of "Dutch disease". This means that high levels of aid inflow cause the overvaluation of exchange rates. Aid would undermine the external competitiveness of the recipient country, thus crowding out investments in the traded goods sector and reducing export earnings.

The failure of the recipient country to accomplish donor conditionality leads to uncertainty of the aid inflow. This could lead both the public and private sectors in the recipient country to postpone or even cancel investment decisions.

Other factors such as changes in relative prices may of course also affect sectoral growth rates but we omitted them because reliable proxies can hardly be constructed in a panel data context.

The metrics' strategy for institutional quality measure of Rajan and Subramanian (2008a) that was reconstructed in Clemens et al. (2012), used a period averages of the sum of three components (bureaucratic quality, rule of law and corruption), the current study used the same three components and added democratic accountability as a fourth component in the metrics to account for some characteristics of the 37 selected sample countries from MENA and SSA regions.

15 Appendix A provides more information about the metrics used in this measure and describes, in detail, all included sectors for each respective sector of interest.

16 Appendix B provides more details on the calculation and definition of early-impact metrics; it also enlists Clemens' classification of early-impact aid categories. 
Masters and Wiebe (2000), for example, suggested that growth in agricultural productivity is restricted in more tropical areas.

\section{References}

Adam, Christopher, and David Bevan. 2006. Aid and the Supply Side: Public Investment, Export Performance, and Dutch Disease in Low-Income Countries. World Bank Economic Review 20: 261-90. [CrossRef]

Addison, Tony, George Mavrotas, and Mark McGillivray. 2005. Aid to Africa: An Unfinished Agenda. Journal of International Development 17: 989-1001. [CrossRef]

Aime, Ramiarsison Herinjatovo. 2010. Assessing the Developmental Role of Foreign Aid in Developing Countries: A Special Reference to The Role of Japan's Aid in Far East Asia. V.R.F. Series 462: 71.

Alabi, Reuben Adeolu. 2014. Impact of Agricultural Foreign Aid on Agricultural Growth in Sub-Saharan Africa. AGRODEP Working Paper 6: 1-39.

Alfaro, Laura, Sebnem Kalemli-Ozcan, and Vadym Volosovych. 2014. Sovereigns, upstream capital flows, and global imbalances. Journal of the European Economic Association 12: 1240-84. [CrossRef]

Alvi, Eskander, Debasri Mukherjee, and Elias Kedir Shukralla. 2008. Aid, Policies, and Growth in Developing Countries: A New Look at the Empirics. Southern Economic Journal 74: 693-706. [CrossRef]

Arellano, Cristina, Ales Bulir, Timothy Lane, Leslie Lipschitz, Cristina Arellano, Ales Bulir, Timothy Lane, and Leslie Lipschitz. 2009. The Dynamic Implications of Foreign Aid and Its Variability. Journal of Development Economics 88: 87-102. [CrossRef]

Arndt, Channing, Sam Jones, and Finn Tarp. 2014. WIDER Working Paper 2014/089 What Is the Aggregate Economic Rate of Return to Foreign Aid? Available online: https://doi.org/10.35188/UNU-WIDER/2014/810-0 (accessed on 30 December 2019).

Basnet, Him. 2013. Foreign Aid, Domestic Savings, and Economic Growth in South Asia. International Business E Economics Research Journal (IBER) 12: 1389-94.

Boone, Peter. 1996. Politics and the Effectiveness of Foreign Aid. European Economic Review 40: 289-329. [CrossRef]

Bourguignon, François, Michael Clemens, James Mirrlees, Jean-David Naudet, Leonce Ndikumana, Jodi Nelson, and Miguel Szekely. 2012. Evaluation and its Discontents: Do We Learn from Experience in Development. Paper presented at the 9th AFD-EUDN Conference, Paris, France, March 26.

Bräutigam, Deborah, and Stephen Knack. 2004. Foreign aid, institutions, and governance in Sub-Saharan Africa. Economic Development and Cultural Change 52: 255-85. [CrossRef]

Breusch, Trevor, and Adrian Pagan. 1980. The Lagrange Multiplier Test and Its Applications to Model Specification in Econometrics. The Review of Economic Studies 47: 239. [CrossRef]

Bulir, Ales, and Javier Hamann. 2008. Volatility of Development Aid: From the Frying Pan into the Fire? World Development 36: $2048-66$. [CrossRef]

Burnside, Craig, and David Dollar. 2000. Aid, Policies, and Growth. American Economic Review 90: 847-68. [CrossRef]

Celasun, Oya, and Jan Walliser. 2008. Predictability of aid: Do fickle donors undermine aid effectiveness? Economic Policy 23: 546-94. [CrossRef]

Chatterjee, Santanu, and Stephen J. Turnovsky. 2005. Financing Public Investment through Foreign Aid: Consequences for Economic Growth and Welfare. Review of International Economics 13: 20-44. [CrossRef]

Chatterjee, Santanu, Georgios Sakoulis, and Stephen Turnovsky. 2003. Unilateral Capital Transfers, Public Investment, and Economic Growth. European Economic Review 47: 1077-103. [CrossRef]

Chatterjee, Santanu, Giuliano Paola, and Kaya Ilker. 2012. Where Has All the Money Gone? Foreign Aid and the Composition of Government Spending. Available online: https://ssrn.com/abstract=1691650 (accessed on 20 August 2019). [CrossRef]

Clemens, Michael, Steven Radelet, and Rikhil Bhavnani. 2004. Counting Chickens When They Hatch: The Short-Term Effect of Aid on Growth. Center for Global Development. Working Paper No. 44. Available online: https:/ / ssrn.com/abstract=567241 (accessed on 12 April 2019).

Clemens, Michael, Steven Radelet, Rikhil Bhavnani, and Samuel Bazzi. 2012. Counting Chickens When They Hatch: Timing and the Effects of Aid on Growth. Economic Journal 122: 590-617. [CrossRef]

Collier, Paul. 2007. The Bottom Billion: Why the Poorest Countries Are Failing and What Can Be Done about It. New York: Oxford University Press, ISBN 0195374630/978-0195374636. Available online: https://www.oxfordmartin.ox.ac.uk/publications/the-bottombillion-why-the-poorest-countries-arefailing-and-what-can-be-done-about-it/ (accessed on 7 August 2019).

Collier, Paul, and David Dollar. 2002. Aid Allocation and Poverty Reduction. European Economic Review 46: 1475-500. [CrossRef]

Dalgaard, Carl Johan, Henrik Hansen, and Finn Tarp. 2004. On the Empirics of Foreign Aid and Growth. Economic Journal 114: 191-216. [CrossRef]

De Melo, Jaime, and Olivier Cadot. 2014. Aid for Trade: What Have We Learnt? Which Way Ahead? London: CEPR Press and FERDI.

Dietrich, Simone, and Joseph Wright. 2012. Foreign Aid and Democratic Development in Africa. In WIDER Working Paper. 2012/020. Helsinki: UNU-WIDER.

Feeny, Simon, and Bazoumana Ouattara. 2009. What Type of Economic Growth Does Foreign Aid Support? Applied Economics Letters 16: 727-30. [CrossRef]

Ferro, Esteban, Alberto Portugal-Perez, and John S. Wilson. 2014. Aid to the Services Sector: Does it Affect Manufacturing Exports? The World Economy 37: 530-41. [CrossRef] 
Findley, Mike, and Darren Hawkins. 2010. To Empower or Impoverish? The Sector-by-Sector Effectiveness of Foreign Aid. Paper presented at the AidData Oxford Conference, Oxford University, Oxford, UK, March 22-25.

Frot, Emmanuel, and Javier Santiso. 2010. Crushed Aid: Fragmentation in Sectoral Aid. In OECD Development Centre Working Papers. ZDB-ID 2143343-4. Paris: OECD, vol. 284, ISSN 1815-1949. [CrossRef]

Gallup, John Luke, Jeffrey D. Sachs, and Andrew D. Mellinger. 1999. Geography and economic development. International Regional Science Review 22: 179-232. [CrossRef]

Ghimire, Shankar, Debasri Mukherjee, and Eskander Alvi. 2013. Sectoral Aid-for-Trade and Sectoral Exports: A Seemingly Unrelated Regression Analysis. Economics Bulletin 33: 2756-62.

Gibson, Clark, Barak Hoffman, and Ryan Jablonski. 2015. Did Aid Promote Democracy in Africa? The Role of Technical Assistance in Africa's Transitions. World Development 68: 323-35. [CrossRef]

Giuliano, Paola, Santanu Chatterjee, and Paola Giuliano. 2007. Where Has All the Money Gone? Foreign Aid and the Quest for Growth. Discussion Paper No. 2858 at IZA. Bonn: IZA.

Goshu, Fikadu. 2014. Sectoral Analysis of the Impact of Foreign Aid on Economic Growth in Ethiopia: Time Series Analysis of Agriculture, Education and Health Sectors. Hamburg: Anchor Academic Publishing, ISBN 978-3-95489-358-4/978-3-95489-858-9.

Gupta, Sanjeev, Benedict Clements, Alexander Pivovarsky, and Erwin Tiongson. 2003. Foreign Aid and Revenue Response: Does the Composition of Aid Matter? IMF Working Paper Vol 2003: Issue 176. Washington, DC: IMF, ISBN 9781451858839. ISSN 1018-5941. [CrossRef]

Gupta, Sanjeev, Robert Powell, and Yongzheng Yang. 2006. Macroeconomic Challenges of Scaling Up Aid to Africa A Checklist for Practitioners. IMF Working Paper. Washington, DC: IMF, ISBN 1589065050.

Hansen, Henrik, and Finn Tarp. 2001. Aid and Growth Regression. Journal of Development Economics 64: 547-70. [CrossRef]

Hugie, Stephanie. 2011. Donor-Side Determinants of Disaggregated Foreign Assistance: A Sur Approach to Understanding U.S. Economic, Military, and Food Aid Commitments. Utah State University, Graduate Studies at DigitalCommons@USU. All Graduate Plan B and Other Reports. 165. Logan, Utah. Available online: https://digitalcommons.usu.edu/gradreports/165 (accessed on 30 July 2019).

Jones, Sam, and Finn Tarp. 2016. Does Foreign Aid Harm Political Institutions? Journal of Development Economics 118: 266-81. [CrossRef]

Kangoye, Thierry. 2013. Does aid unpredictability weaken governance? Evidence from developing countries. The Developing Economies 51: 121-44.

Keza, Jean-Placide. 2005. Valeurs Culturelles et Échec de L'aide Au Développement: Application À l'Afrique Subsaharienne. Paris: L'Harmattan.

Kharas, Homi. 2008. Measuring the Cost of Aid Volatility. SSRN Electronic Journal Paper 3: 1-36. [CrossRef]

Lamb, Helen. 1954. NURKSE, RAGNAR. Problems of Capital Formation in Underdeveloped Countries. New York: Oxford University Press. 1953. The ANNALS of the American Academy of Political and Social Science 294: 194-95.

Lewis, Arthur. 1954. Economic Development with Unlimited Supplies of Labour. The Manchester School 22: 139-91. [CrossRef]

Makuyana, Garikai, and Nicholas Odhiambo. 2016. Public and Private Investment and Economic Growth. Journal of Accounting and Management 6: 25-42.

Masters, William A., and Keith D. Wiebe. 2000. Climate and Agricultural Productivity. Cambridge: Center for International Development Working Paper, Harvard University.

McArthur, John, and Jeffrey Sachs. 2019. Agriculture, Aid, and Economic Growth in Africa. World Bank Economic Review 33: 1-20. [CrossRef] [PubMed]

Mukherjee, Debasri, and Elsy Thomas Kizhakethalackal. 2013. Empirics of Health-Aid, Education and Infant Mortality: A Semiparametric Study. Applied Economics 45: 3137-50. [CrossRef]

Ndikumana, Leonce. 2012. Appliquer l'Évaluation À L'aide Au dÉveloppement: Une Solution Pour Combler Le fossÉ Micro-Macro de l'efficacitÉ de L'aide? Revue d'Economie Du Developpement 26: 125-53. [CrossRef]

Ndikumana, Léonce, and Lynda Pickbourn. 2017. The Impact of Foreign Aid Allocation on Access to Social Services in Sub-Saharan Africa: The Case of Water and Sanitation. World Development 90: 104-14. [CrossRef]

Nkusu, Mwanza, and Selin Sayek. 2004. Local Financial Development and the Aid-Growth Relationship. IMF Working Papers. Washington, DC: IMF, vol. 2004, ISBN 9781451875775. ISSN 1018-5941. [CrossRef]

Norton, George, Jaime Ortiz, and Philip Pardey. 1992. The Impact of Foreign Assistance on Agricultural Growth. Economic Development $\mathcal{E}$ Cultural Change 40: 775-86.

Nyoni, Thabani, and Wellington Garikai Bonga. 2017. Foreign aid-economic growth nexus: A systematic review of theory \& evidence from developing countries. Dynamic Research Journals' Journal of Economics \& Finance 2: 1-16.

Odusanya, Ibrahim Abidemi, Abidemi Logile, and Lateef Olawale Akanni. 2011. Foreign Aid, Public Expenditure and Economic Growth: The Nigerian Case. Journal of Applied Business Research 27: 33-42. [CrossRef]

OECD. 2011. Development: Aid to Developing Countries Falls Because of Global Recession. (Africa3). Available online: https: //www.oecd.org/newsroom/developmentaidtodevelopingcountriesfallsbecauseofglobalrecession.htm (accessed on 2 June 2019).

Pack, Howard, Janet Rothenberg Pack, Howard Pack, and Janet Rothenberg Pack. 1993. Foreign Aid and the Question of Fungibility. The Review of Economics and Statistics 75: 258-65. [CrossRef]

Page, John, and Abebe Shimeles. 2015. Aid, Employment and Poverty Reduction in Africa. African Development Review 27: 17-30. [CrossRef] 
Pickbourn, Lynda, and Léonce Ndikumana. 2016. The Impact of the Sectoral Allocation of Foreign Aid on Gender Inequality. Journal of International Development 28: 396-411. [CrossRef]

Pindiriri, Carren. 2012. Aid Effectiveness, Development Theories and Their Influence on the Structure and Practices in Development Aid to 3rd World Countries. Research Gate. Available online: https://www.researchgate.net/publication/269035512_ (accessed on 11 December 2018).

Pöntinen, Laura. 2014. Sectoral Allocation of Aid: What Has Changed? CESifo DICE Report 12: 58-60.

Rajan, Raghuram, and Arvind Subramanian. 2007. Does aid affect governance? American Economic Review 97: 322-27. [CrossRef]

Rajan, Raghuram, and Arvind Subramanian. 2008a. Aid and Growth: What Does the Cross-Country Evidence Really Show? Review of Economics and Statistics 90: 643-65. [CrossRef]

Rajan, Raghuram, and Arvind Subramanian. 2008b. Aid and Manufacturing Growth. Washington, DC: IMF, Mimeo.

Rajan, Raghuram, and Arvind Subramanian. 2011. Aid, Dutch Disease, and Manufacturing Growth. Journal of Development Economics 94: 106-18. [CrossRef]

Rajan, Raghuram, and Luigi Zingales. 1998. Financial Dependence and Growth. American Economic Review 88: 559-86.

Roodman, David. 2015. A Replication of 'Counting Chickens When They Hatch' (Economic Journal 2012). Public Finance Review 43: 256-81. [CrossRef]

Rosenstein-Rodan, Paul N. 1943. Problems of Industrialisation of Eastern and South-Eastern Europe. The Economic Journal 53: 202. [CrossRef]

Rostow, Walt Whitman. 1960. The Stages of Economic Growth: A Non-Communist Manifesto-Walt Whitman Rostow, W. W. Rostow-Google Books. London: Cambridge University Press.

Savun, Burcu, and Daniel Tirone. 2011. Foreign Aid, Democratization, and Civil Conflict: How Does Democracy Aid Affect Civil Conflict? American Journal of Political Science 55: 233-46. [CrossRef]

Selaya, Pablo, and Rainer Thiele. 2010. Aid and Sectoral Growth: Evidence from Panel Data. Journal of Development Studies 46: $1749-66$. [CrossRef]

Sethi, Narayan, Padmaja Bhujabal, Aurolipsa Das, and Sanhita Sucharita. 2019. Foreign aid and growth nexus: Empirical evidence from India and Sri Lanka. Economic Analysis and Policy 64: 1-12. [CrossRef]

Shahzad, Umer, and Fengming Qin. 2019. New Terrorism and Capital Flight: Pre and Post Nine Eleven analysis for Asia. Annals of Economics E Finance 20: 465-87.

Ssozi, John, Simplice Asongu, and Voxi Heinrich Amavilah. 2019. The Effectiveness of Development Aid for Agriculture in Sub-Saharan Africa. Journal of Economic Studies 46: 284-305. [CrossRef]

Tait, Lauren, Abu Siddique, and Ishita Chatterjee. 2015. Foreign Aid and Economic Growth in Sub-Saharan Africa. Economics Discussion/Working Papers 15-35. Crawley: Department of Economics, The University of Western Australia.

WDI. 2021. World Development Indicators I DataBank. Available online: https:// databank.worldbank.org/reports.aspx?source= world-development-indicators\# (accessed on 11 December 2021).

Whiteside, Alan. 2010. Dead Aid: Why Aid Is Not Working and How There Is a Better Way for Africa. Global Public Health 5: 197-98. [CrossRef]

Williamson, Claudia. 2008. Foreign Aid and Human Development: The Impact of Foreign Aid to the Health Sector. Southern Economic Journal 75: 188-207. [CrossRef]

Xayavong, Vilaphonh, Rukmani Gounder, and James Obben. 2005. Theoretical Analysis of Foreign Aid, Policies and State Institutions. Discussion Papers 23704. Palmerston North: Massey University, Department of Applied and International Economics.

Zellner, Arnold. 1962. An Efficient Method of Estimating Seemingly Unrelated Regressions and Tests for Aggregation Bias. Journal of the American Statistical Association 57: 348-68. [CrossRef] 